\title{
Sustainable Business models in Biosphere Reserves: Case of Hungary
}

\author{
Amir Mosavi \\ School of the Built Environment, Oxford Brookes University, Oxford OX3 0BP, UK. and \\ Institute of Automation, Kalman Kando Faculty of Electrical Engineering, Obuda University, \\ Budapest, Hungary. Email:a.mosavi@brookes.ac.uk
}

\begin{abstract}
The goal of Man and the Biosphere (MAB) Programme is to support sustainable development through effective management, innovative technologies, policy suggestion and governance. Today, the concept of Biosphere Reserves plays an important role in scientific investigations, generating knowledge, and experiences to link socio-economic development and biodiversity conservation for human well-being.
\end{abstract}

This research, through an independent study which takes place in the Hungarian Biosphere Reserves of Pilis and Kiskunság aims at identifying practical sustainable business models which are suitable for supporting livelihood of locals. In this research, the two Biosphere Reserves serve as the learning sites under the light of global principles and state-of-the-art-of knowledge on sustainable development and sustainable business models. To do so, the state-of-the-art-of sustainable business model has been investigated through a comprehensive academic research. The lessons that learned from this investigation are used to support the data gathering method and planning the field trips to identify the sustainable business models currently in use at the Biosphere Reserves. This research particularly had been interested in small-sized sustainable business models practiced by small communities or families in various zones of Biosphere Reserves. 
First set of interviews and questionnaires designed to identify the business models in practice. The results identify foraging the wild plants in the buffer zone and transition areas as a potential sustainable business model in practice. Further interviews and surveys were conducted with foragers shows the beneficial of their practice on the local ecosystem and in increasing awareness on the deep connection with the ecosystems. The sustainable business model of foraging in addition to providing a sustainable livelihood for the locals maintains a spiritual connection between people and land. The identified sustainable business model can further be educational and practical for other 685 biosphere reserves.

Keywords: sustainable development; sustainability; biosphere reserves; business models; sustainable business models; climate protection; climate change adaptation; resilience 


\section{Table of Contents}

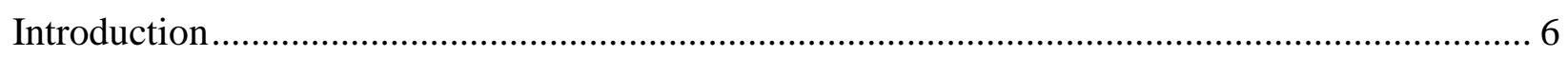

Section 1: State-of-the-art of sustainable business models ..................................................... 8

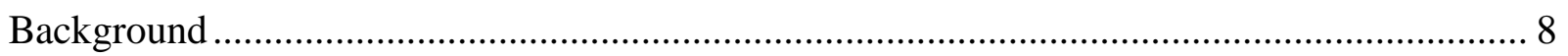

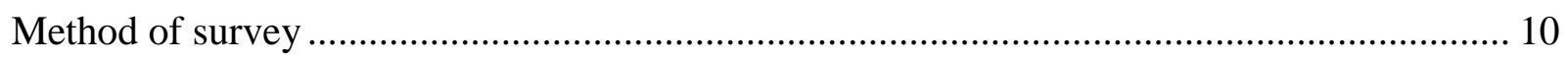

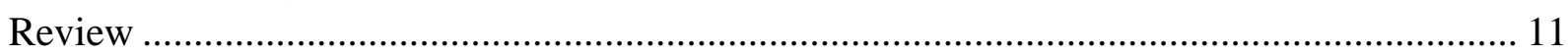

Sustainable business models in Innovation and design ........................................... 11

Sustainable business models in Management................................................................. 12

Sustainable business models in energy domain ...................................................... 14

Sustainable Business Models in Clothing ................................................................. 15

Sustainable business models in Health .......................................................................... 16

Sustainable business models for agriculture............................................................... 16

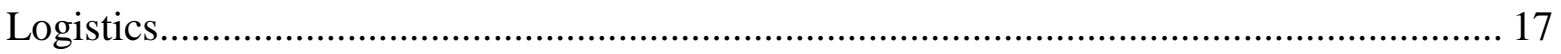

Sustainable business models for circular economy …................................................ 18

Sustainable business models in Third World countries cases .......................................... 19

Sustainable business model in civil engineering ............................................................ 20

Sustainable business models in Tourism industry ..................................................... 21

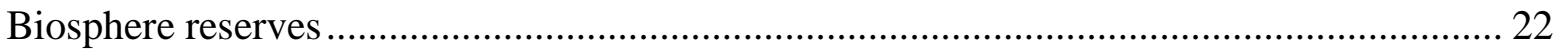

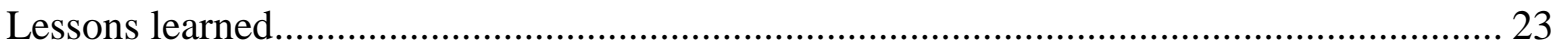

Section 2: Sustainable business Models in Biosphere Reserves of Hungary ........................... 26

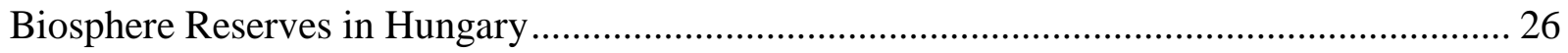

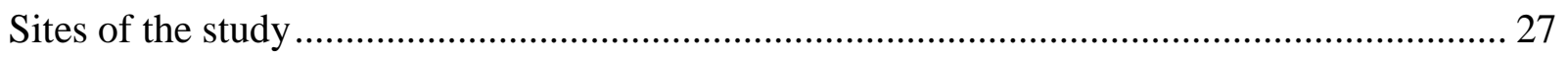

Pilis Biosphere Reserve ............................................................................................ 34

Studying foraging as the sustainable business model ..................................................... 37

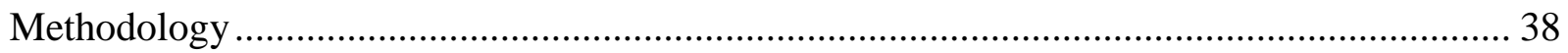

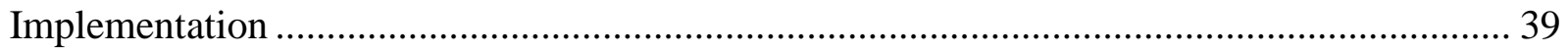

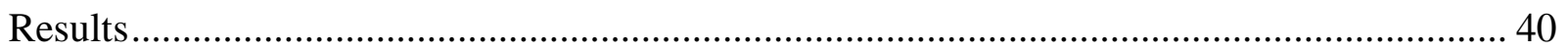

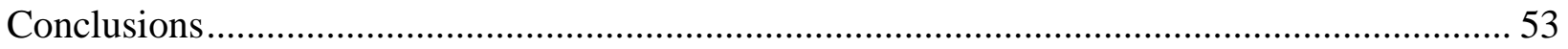

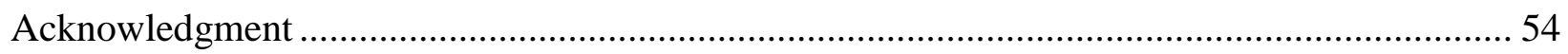




\section{Table of Figures}

Figure 1. The increasing trend in employing sustainable business models ............................... 9

Figure 2. sustainable business models in different subject areas.......................................... 10

Figure 3. Characteristics of a sustainable business model for biosphere reserves...................... 24

Figure 4. Biosphere Reserves in Hungary ...................................................................... 26

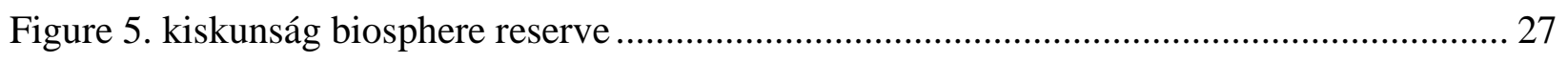

Figure 6. Fellow in a field trip in Kiskunság Biosphere Reserve ............................................ 28

Figure 7. Numerous hospitality business around the Kiskunság Biosphere Reserve ................. 29

Figure 8. Tanya: Hungarian farm for hospitality and horse shows, Kiskunság......................... 29

Figure 9 Tanya: Hungarian farm for hospitality and horse shows, Kiskunság.......................... 30

Figure 10. Tanya: Hungarian farm for hospitality and horse shows, Kiskunság ....................... 30

Figure 11. Tanya: Hungarian farm for livestock farming, Kiskunság .................................... 31

Figure 12. Tanya: Hungarian farm for livestock farming, Kiskunság .................................... 31

Figure 13. Tanya: Hungarian farm for livestock farming, Kiskunság ..................................... 32

Figure 14. Farms around the Kiskunság Biosphere Reserve ............................................... 32

Figure 15. Farms around the Kiskunság Biosphere Reserve ............................................... 33

Figure 16. Farms around the Kiskunság Biosphere Reserve ............................................... 33

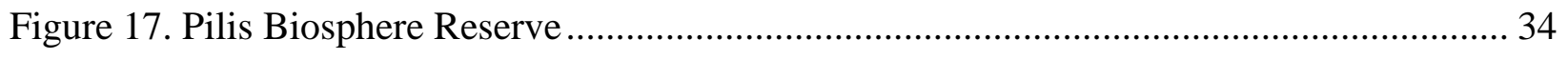

Figure 18. Field trip in Pilis Biosphere Reserve .............................................................. 35

Figure 19. Fellow on field trip in Pilis Biosphere Reserve, looking for foragers ...................... 35

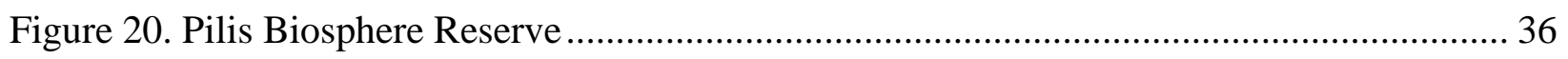

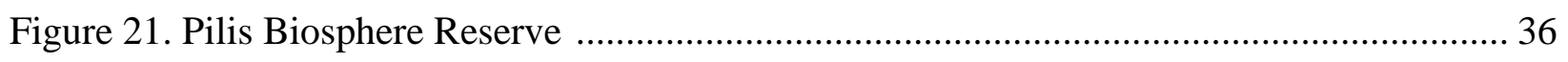

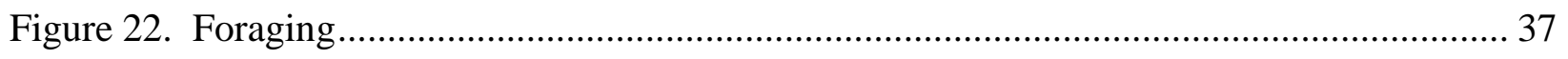

Figure 23. Foraging, the potential sustainable business model of Biosphere Reserves .............. 37

Figure 24. there are more than 50 plants species which can be foraged sustainably.................. 38

Figure 25. sustainable foraging practice (Photo credit: Dániel B. Kovács) ............................. 41

Figure 26. Medvehagyma / Beer leek (Photo credit: Dániel B. Kovács) .................................. 42

Figure 27. Mezei zsálya / Clary (Photo credit: Dániel B. Kovács) .......................................... 42

Figure 28. Local foraging community (Photo credit: Dániel B. Kovács) ................................. 43

Figure 29. new generations are trained on sustainable

foraging. .44 
Figure 30. Fellow foraging around Kiskunság Biosphere Reserve Amir Mosavi) ..................... 45

Figure 31. Fellow foraging around Kiskunság Biosphere Reserve ........................................ 45

Figure 32 drying (Photo credit: Amir Mosavi) ................................................................... 46

Figure 33. drying and processing plants (Photo credit: Dániel B. Kovács) .............................. 46

Figure 34. drying and processing plants (Photo credit: Amir Mosavi)..................................... 47

Figure 35. tea is one of the major products of foraging plants ............................................ 48

Figure 36. community contribution on processing the plants .............................................. 48

Figure 37. packaging for selling in a local market or personal use ........................................ 49

Figure 38. packaging for selling in a local market or personal use ........................................ 49

Figure 39. local tea house (Photo credit: Dániel B. Kovács) ................................................ 50

Figure 40. local sales of packaged plants as herbal teas ..................................................... 50

Figure 41. local sales of packaged plants as herbal teas ................................................... 51

Figure 42 Conceptual Framework (Giesting - 2016) ..................................................... 51

Figure 43. sustainable business model of foraging for Biosphere reserves ............................. 52 


\section{Table of Tables}

Table 1. broad applications areas of sustainable business models.......................................... 10

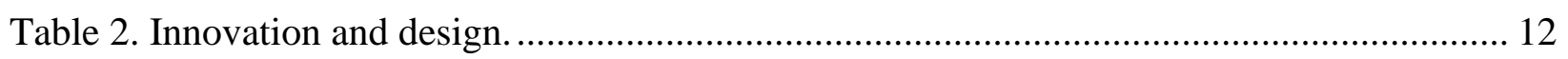

Table 3. Sustainable business models in the management ................................................... 13

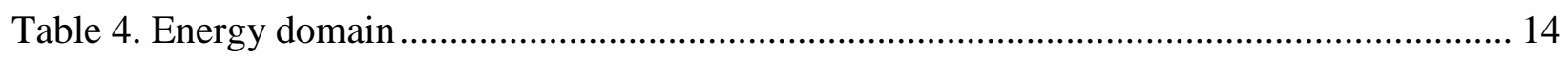

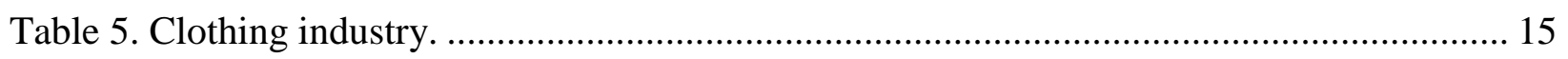

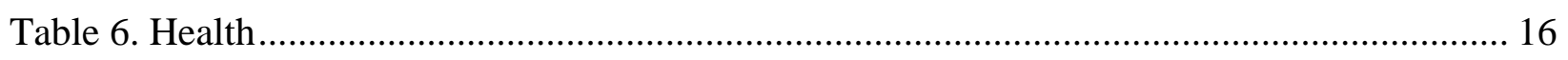

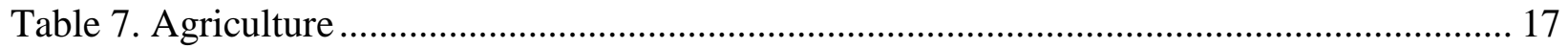

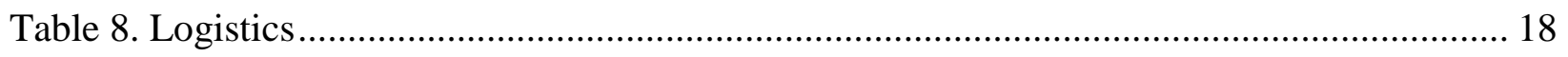

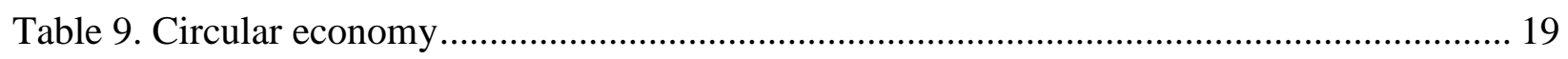

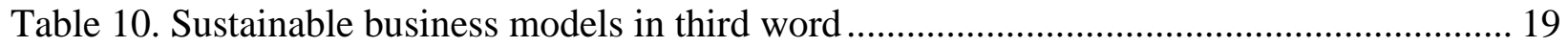

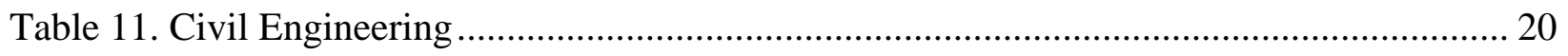

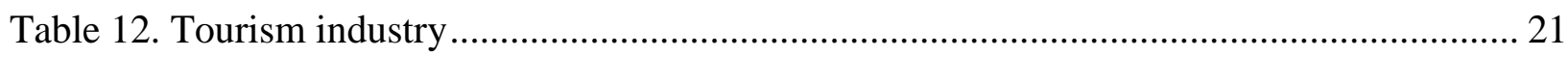

Table 13. Sustainable business model in Biosphere reserves .............................................. 22 


\section{Introduction}

our research is concerned with the sustainable development in biosphere reserves. Sustainable development is defined as an economic development for meeting human development goals while maintaining the ability of natural systems to regenerate. The Man and the Biosphere Programme fosters the research on sustainable development which harmonizes the conservation of biodiversity with the sustainable use of natural resources in respect to economic development. Among the principals of ecosystem management in the biosphere reserves, sustainability is considered as the primary goal of economic development and natural recourse management (Peine 1998). Nonetheless the management of values, boundaries, health, stability, diversity, and knowledge considered as important. Planning and managing for sustainability require the particular focus on long-term consequences which aims at the rational and sustainable use and conservation of the resources of the biosphere and for the improvement of the overall relationship between people and biosphere reserves. This would require a monitoring and assessment model to measure and evaluate the sustainability. This research proposes sustainable business modeling (Mosavi \& Delavar 2016) aiming at economic development in Biosphere reserves that are socially and culturally appropriate, and environmentally sustainable.

Sustainable Business Model of the Biosphere Reserve- managing the biosphere reserves is challenged with the uncertain economic, dynamic of the business environments and interrelationships which are highly affected by climate change, globalization, increasing complexity and information technologies. Therefore, we need useful tools to understand, assess, predict, and improve business models. Business model of a reserve is an abstract representation of profit sharing and value architecture which can identify the behavior and function of a reserve toward equitability and sustainability. Recent environmental, economic, and financial worldwide crises have raised important attention to the importance of sustainable business models. A sustainable business model is a conceptualvisual representation tool that contains a set of elements and their relationships expressing a system of equitable sharing of benefits while managing ecosystems. Thus, promoting innovative approaches to economic development that are socially and 
culturally appropriate, and environmentally sustainable. Such model provides the ability to predict the consequences of today's actions to ensure an efficient management of natural resources for the well-being of both human populations and the environment in addition to maintain sustainable development. This would lead to improve the livelihood and appreciation of the people living in biosphere zones. The business model can represent, educate and communicate the reserve better in both national and international level and foster economic and human development. Once the business model of a reserve is created, with the better insight, the improvement toward more sustainable business model can be managed. The general research purpose is concerned with the potential of business modeling for sustainable development at two different sites of Kiskunság Biosphere Reserve, and Pilis Biosphere Reserve in Hungary. By implementation and comparison of the two sustainable business models we aim at finding an innovative solution to restore the conservation of biodiversity with its sustainable use. The goal of sustainable business models would be the transformation toward development without threaten of natural resources within the limits of a sustainable ecosystem. To do so this research conducts an interdisciplinary approach to address the management of sustainable development with respect to sustainability of social, environmental and economic issues to prevent conflict and support the land, water, ecosystems and biodiversity. This would be facilitated via a better monitoring and assessment (Mosavi \& Delavar 2016).

In section 1 , the state-of-the-art of sustainable business models are presented in a wide range of application domains. This section provides the lessons learned. In Section two, based on the lessons learned, the sustainable business models in biosphere reserves are considered. This section follows with introducing the foraging for tea making as a potential sustainable business in biosphere reserves of study which can be used in other places as well. 


\section{Section 1: State-of-the-art of sustainable business models}

At the time of initiating this research there was no scientific literature available of the state-of-the-art of sustainable business models. This has been a motivation to carry out an independent research on this realm to investigate the novel sustainable models and bring insight on the latest sustainable business models used in the various business domains. PhD student Saeed Nosratabadi contributed in this section with his background and expertise in sustainable business model (Nosratabadi and Mosavi 2018).

A sustainable business model describes the rationale of how an individual or an organization creates value in a sustainable way. The process of constructing a sustainable business model forms an innovative part of business strategy. Today, organizations utilize sustainability business models to satisfy their economic, environmental and social goals simultaneously. This section is designd to survey sustainable business models in various fields to provide an overall insight for delivering valuable lessons. Here, the sustainable business models are categorized and reviewed.

\section{Background}

Today, businesses are struggling with finding the solutions to win the competition. The competitions have become much tougher the efficiency and profitability has turned into necessities. Focusing on profitability has neglected the possible impacts that such economic activities have on ecosystem. Nevertheless, there has been an increasing trend environmentally conscious business model. The increasing the number of literatures during the past decade provides a clear perspective on this trend. In fact, a primary investigation in the literature shows a meaningful increase in the number of publications on the topic of sustainable business model, as it is shown in the figure 1. 


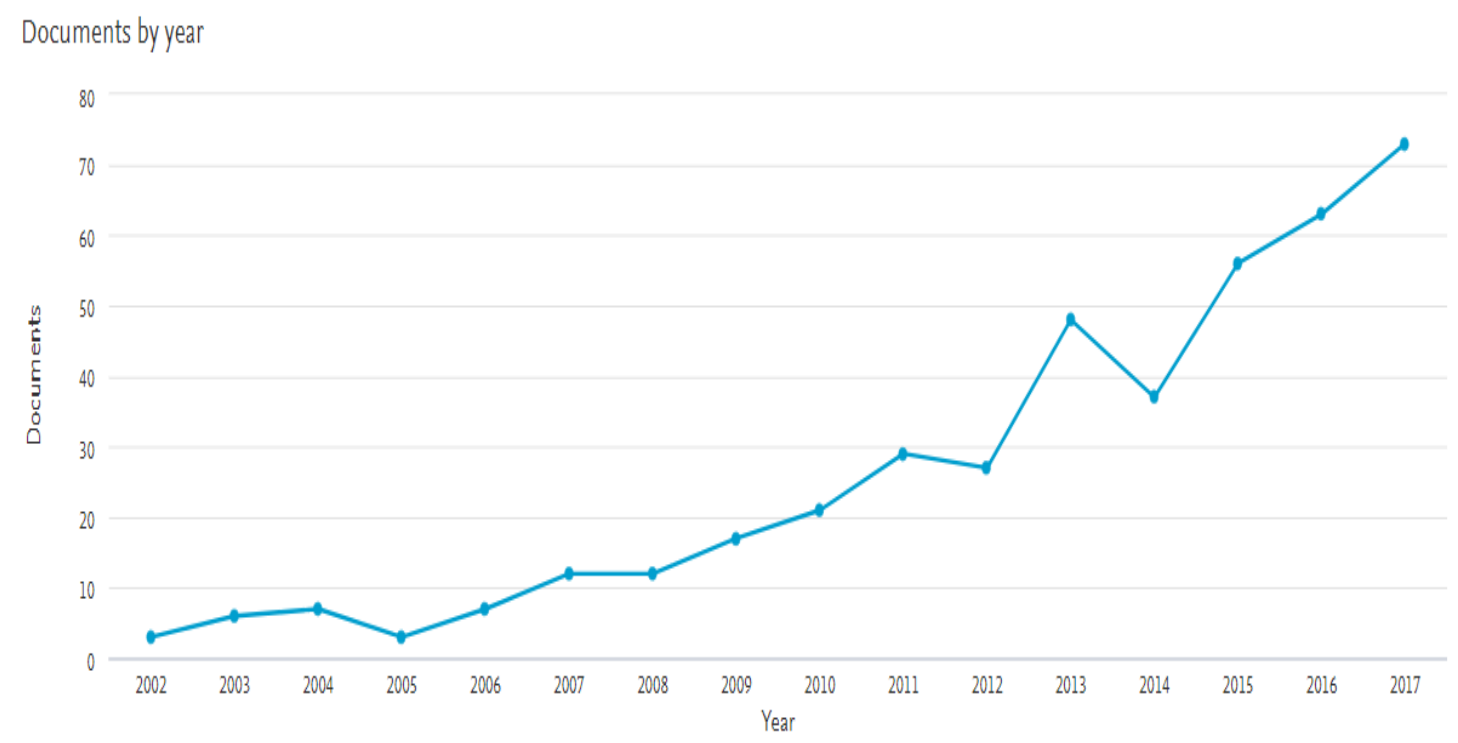

Figure 1. The increasing trend in employing sustainable business models

The nature of the business domain is very determinant in the sustainability approach. Nevertheless, the business profitability of multiple-stakeholders i.e., customers, suppliers, shareholders are affected using sustainable models (Stubbs and Cocklin 2008, Bocken, Short et al. 2014, Rauter, Jonker et al. 2017). Therefore, transition toward sustainability requires innovation actions to maintain the value. (Ashford and Hall 2011, Boons, Montalvo et al. 2013)]. The journals of Cleaner Production and Sustainability have well contributed in the ideology of sustainable business models.

According to figure 2, sustainable business models had been contributing to a wide range of domains including management, production, sales, truism, hospitality, accounting, engineering, environmental science, social science and a tiny fraction in biosphere reserves. In fact, there is a gap in research on the advancement of sustainability methods in biosphere reserves. Table 1 shows the number article published in various categories. 

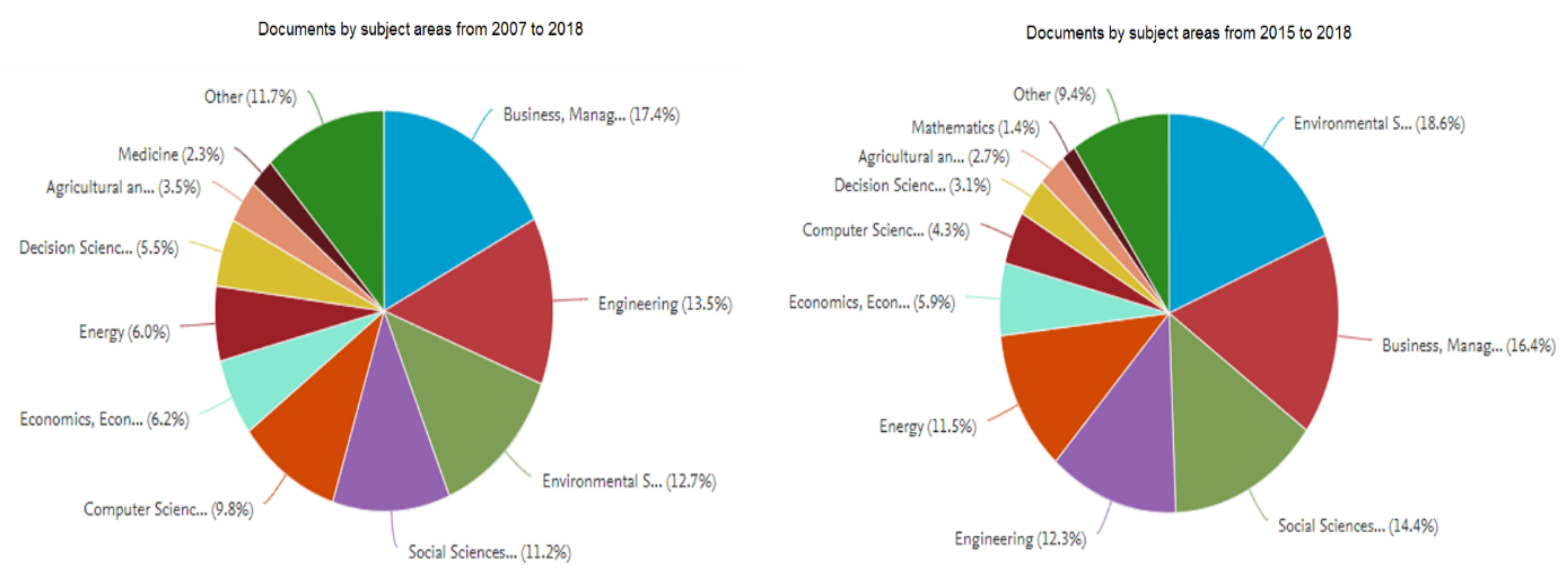

Figure 2. sustainable business models in different subject areas.

Table 1. broad applications areas of sustainable business models

\begin{tabular}{cc}
\hline Subject area & $\begin{array}{c}\text { No of } \\
\text { Documents }\end{array}$ \\
\hline Environmental Science & 687 \\
Business, Management and Accounting & 603 \\
Social Sciences & 531 \\
Engineering & 454 \\
Energy & 425 \\
Economics, Econometrics and Finance & 216 \\
Computer Science & 158 \\
Decision Sciences & 115 \\
Agricultural and Biological Sciences & 100 \\
Medicine & 50 \\
Earth and Planetary Sciences & 47 \\
Materials Science & 38 \\
Chemical Engineering & 30 \\
Multidisciplinary & 17 \\
Health Professions & 10 \\
Biosphere reserves & 8 \\
\hline
\end{tabular}

\section{Method of survey}

The keywords of "sustainable business model" and "sustainable development" has been used to explore the literature on this realm which primarily results in more than 3000 original articles in 27 different subject areas. When we narrow our search to the particular application domains the number of articles drop to 100. 


\section{Review}

Sustainable business models urge the firms to integrate their profit objectives with the sustainability goals (Rashid, Asif et al. 2013). (Porter and Kramer 2011) describe sustainability as the sources of competitive advantage in value creation. They explain a number of characteristics for a sustainable business model which distinguishes it from a traditional business model. They believe that the value proposition of SBMs is an ecological or social value in accordance with economic value. (Abdelkafi and Täuscher 2016) describe sustainability in business models as tools incorporating value proposition. Furthermore, (Geissdoerfer, Bocken et al. 2016) count a number of elements in which the interrelation between these elements and their interactions with the stakeholders. Besides, many literatures, have used this concept to provide possible solutions for the businesses for sustainable development. The following review overview in details how sustainable business models are applied in a wide range of application. From this review a number of lessons further are learned and a sample business model for biosphere reserves is suggested.

\section{Sustainable business models in Innovation and design}

(Evans, Vladimirova et al. 2017) suggests several paradigms for innovation transformation for sustainable business model. In a similar work, (Evans, Vladimirova et al. 2017) suggests a novel sustainable business model to drive sustainable value for innovation. They create a system of sustainable value for multiple stakeholders which is generating a sustainable value network toward a novel sustainable business model. The other paradigm to design a sustainable business model is to reconsider the stakeholders' interests for mutual value creation. Finally, internalizing externalities through Product Service System also enables innovation towards SBMs. (Geissdoerfer 2016) developed the concept of value proposition in design and prototyping. According to (Evans, Vladimirova et al. 2017) and (Biloslavo, Bagnoli et al. 2018) a sustainable business model is to design a sustainable value proposition through identifying formerly underserved stakeholders. 
(Oskam, Bossink et al. 2018) propose value shaping for innovations for environmental value that a business create. They argue that redirecting value refers to shifting from the current value to a sustainable one. (Joyce and Paquin 2016) further provide a novel approach to design a sustainable business model. Sustainable Business Model Canvas to meet environment requirement of a business model. (Roman, Liu et al. 2018) also propose a novel approach to design a sustainable business model through comprising three stages of identifying the possible opportunities, recognizing the barriers.

Table 2. Innovation and design.

\begin{tabular}{ccccc}
\hline Author/s & Year & Contribution & Methodology & Data Source \\
\hline $\begin{array}{c}\text { Evans et al [(Evans, } \\
\text { Vladimirova et al. 2017)] }\end{array}$ & 2017 & Framework & Qualitative & Literature synthesis \\
$\begin{array}{c}\text { Biloslavo, Bagnoli and } \\
\text { Edgar [(Biloslavo, }\end{array}$ & 2018 & Framework & Qualitative & Case Study \\
Bagnoli et al. 2018)] & & & & \\
Oskam, Bossink, and de & & & & \\
Man [(Oskam, Bossink et & 2018 & Framework & Qualitative & interview, secondary data \\
al. 2018)] & & & & \\
& & & & \\
Roman, Liu, and Nyberg & 2016 & Framework & Qualitative & \\
[(Roman, Liu et al. 2018)] & & & & \\
\hline
\end{tabular}

\section{Sustainable business models in Management}

Business models contribute in implementing the business strategies. Therefore, it highly contributes to the goals of the firms. (Stubbs 2017) studies the characteristics the sustainable business models in regard to managerial aspects of innovation. (Morioka, Bolis et al. 2018) presents a multiple case studies in implementing sustainable business models in organizations. Nevertheless, the role of managers in business model implementation is dismissed. (Kurucz, Colbert et al. 2017), however, 
explain that how relational leadership advance the design and assessment of sustainable business models. The role of managerial has been highlighted in supporting sustainable organization management where the the future-fit business benchmark defines the ultimate goal of a sustainable socio-ecological system. In fact, a business model elucidates how a business makes money through value proposition, value creation and value delivering. Thus, the core concept in business model is "value". The value that the customer is ready to pay for it. Most of the marketing activities are dedicated in diagnosing the customers' needs so as for providing such value for them.

(Tolkamp, Huijben et al. 2018) describes how utilizing a user-centered approach to design a sustainable business model is the key to sustainable business model. They identif the customer needs into the firm's value proposition. Further, (Baldassarre, Calabretta et al. 2017) explained the principles user-driven innovation through designing a sustainable value proposition in which potential customers are engaged in the design of value proposition. (De Bernardi and Tirabeni 2018) intended to design a sustainable business model that enhance materialization behaviors. They proposed sustainable business model for food assembly.

Table 3. Sustainable business models in the management

\begin{tabular}{ccccc}
\hline Author/s & Year & Contribution & Methodology & Data Source \\
\hline $\begin{array}{c}\text { (Morioka, Bolis } \\
\text { et al. 2018) }\end{array}$ & 2018 & Framework & Qualitative & Case Study \\
$\begin{array}{c}\text { (Kurucz, Colbert } \\
\text { et al. 2017) }\end{array}$ & 2017 & $\begin{array}{c}\text { Conceptual } \\
\text { model }\end{array}$ & Qualitative & Literature synthesis \\
$\begin{array}{c}\text { (Baldassarre, } \\
\text { Calabretta et al. }\end{array}$ & 2017 & Framework & Qualitative & Case Study \\
2017) & & & & \\
\hline
\end{tabular}




\section{Sustainable business models in energy domain}

One of the objectives of sustainable business model is to eliminate the dictructive effect of the businesses on the ecosystem. Management of the energy is of particular importance in this regard. (Moschetti, Brattebø et al. 2018) proposed an analytic process based on sustainability analyses, to toward achieving sustainable values. Similarly, (Sousa-Zomer and Cauchick Miguel 2018) investigate how sustainable business models may support technological innovations in energy domain. Their founding revealed that a sustainable business model can improve consumers' acceptance, risk perception, and confidence in decentralized approaches. (Zhang, Guo et al. 2018) also propose a framework which help developing sustainable business models for oil companies.

(Rossignoli and Lionzo 2018) presents empirical evidence of new forms of interdependencies arising within partnership networks drive businesses in the energy sector to have a sustainable business model. He believes that a network induces its contributors to expand their definition of value and requires them to create value for both companies and society as the main objective of their business model. According to (Rossignoli and Lionzo 2018) and (Nichifor 2015) the new links among participants of a network create new approaches for capturing value and assist them to solve the concerns related to the resource dependency, which is achieving sustainability goals.

Table 4. Energy domain

\begin{tabular}{ccccc}
\hline Author/s & Year & Contribution & Methodology & Data Source \\
\hline $\begin{array}{c}\text { (Moschetti, Bratteb } \varnothing \\
\text { et al. 2018) }\end{array}$ & 2018 & Model & Quantitative & Literature synthesis \\
$\begin{array}{c}\text { (Zhang, Guo et al. } \\
\text { 2018) }\end{array}$ & 2018 & Framework & Qualitative & case study \\
& & & & \\
(Rossignoli and & 2018 & Empirical & Qualitative & questionnaire \\
\hline
\end{tabular}




\section{Sustainable Business Models in Clothing}

(Pal and Gander 2018) describes traditional business models for clothing industry as a distractive business ecosystem. It is widely claimed that the clothing and fashion industries are unsustainable (Ciasullo, Cardinali et al. 2018). (Kozlowski, Searcy et al. 2018) and (Hirscher, Niinimäki et al. 2018) present the black side of this industry and demonstrate the need for sustainable models and a reform in the industry. (Jung and Jin 2016) investigated the profitability of this industry suing sustainable business model. Customer value creation framework, which is one of the slow fashion solutions, refers to creating perceived customer value. (Pal and Gander 2018) argue that incongruence of fashion customers' value with the value propositions and the barriers in transition of supply chain toward a slowing and a closing loop of resources are detrimental to developing a sustainable business model in the fashion industry. They further believe that development of a suitable business model should be considered as a system for creating value for the customer and environmental and capturing value following the ecosystem values.

Table 5. Clothing industry.

\begin{tabular}{ccccc}
\hline Author/s & Year & Contribution & Methodology & Data Source \\
\hline $\begin{array}{c}\text { (Pal and Gander } \\
\text { 2018) }]\end{array}$ & 2018 & $\begin{array}{c}\text { Theoretical } \\
\text { Evidence }\end{array}$ & Qualitative & Literature \\
$\begin{array}{c}\text { (Hirscher, } \\
\text { Niinimäki et al. } \\
\text { 2018)] }\end{array}$ & 2018 & Framework & Qualitative & interviews \\
& & & & \\
$($ Kozlowski, & 2018 & Framework & Qualitative & interviews \\
Searcy et al. $)]$ & & & & \\
\hline
\end{tabular}




\section{Sustainable business models in Health}

A review on the business model in healthcare industry has been done by (Nikou and Bouwman 2017). They suggest that sustainable business models in the healthcare industry can be adopted through careful consideration of value proposition, organizing and revenue models to provide economic benefits. (Merchant, Ward et al. 2015) further describe that utilizing IT can highly contribute to sustainability. Their results show that, hospitals had been long involved in the design of sustainable business models in this regard. (Anwar and Prasad 2018) show how hospitals use telemedicine solutions for developing a sustainable business models in the healthcare industry and further recommend a continuous eHealth literacy. Through a more advanced telemedicine services considering the user- friendly and sustainable aspects the sustainable business models can be more improved.

Table 6. Health

\begin{tabular}{ccccc}
\hline Author/s & Year & Contribution & Methodology & Data Source \\
\hline (Nikou and Bouwman 2017) & 2017 & Theoretical evidence & Qualitative & Literature synthesis \\
(Merchant, Ward et al. 2015) & 2015 & $\begin{array}{c}\text { Theoretical \& } \\
\text { empirical evidence }\end{array}$ & Qualitative & interviews \\
(Anwar and Prasad 2018) & 2018 & Framework & Quantitative & Literature \\
\hline
\end{tabular}

\section{Sustainable business models for agriculture}

(Barth, Ulvenblad et al. 2017) show that sustainable solutions for business models in agriculture has dramatically increased during the past few years. (Franceschelli, Santoro et al. 2018) describe sustainability in this realm. They contribute to the 
concept of sustainable innovation within the business model literature where they utilize business model canvas to produce an innovative sustainable business model.

Table 7. Agriculture

Author/s

Year

2017

2017)

(Franceschelli, Santoro et

al. 2018)

(Robinson, Cloutier et al. 2017)
2018

2017
Contribution

Methodology

Qualitative

Framework

Theorical

Evidences

Qualitative

Case study

Empirical

Evidences
Data Source

literature review

\section{Logistics}

Logistics is another sector that sustainability business model solutions can highly contribute. As (Witjes and Lozano 2016) explains the objective of sustainability is to address environmental and socio-economic issues in the long term. (Ray and Mondal 2017) further provide evidences illustrate that collaboration is better than competition to maintain sustainability. They argue that in a collaborative business model, suppliers gain experiences in improving circular economy objectives (Geissdoerfer, Morioka et al. 2018) proposes the circular business model concept in logistics. They disclose that circular business model for logistics provides different solutions. Furthermore, (Brennan and Tennant 2018) conducted a comparative case study to discover trade-offs in sustainable logistics. They realized that for transition from a traditional supply network toward sustainable supply network, business model innovation requires to create sustainable values and resolve trade-offs. 
Table 8. Logistics

\begin{tabular}{lcccc}
\hline \multicolumn{1}{c}{ Author/s } & Year & Contribution & Methodology & Data Source \\
\hline (Ray and Mondal 2017) & 2017 & Framework & Qualitative & Systematic literature review \\
(Witjes and Lozano 2016) & 2016 & Theorical & Qualitative & Literature synthesis \\
(Geissdoerfer, Morioka et al. & 2018 & Framework & Qualitative & interviews \\
\hline 2018) & & & & \\
\hline
\end{tabular}

\section{Sustainable business models for circular economy}

Circular economy is a definition of implementation and designing a sustainable business model in the different application areas. (Geissdoerfer, Morioka et al. 2018) utilized circular economy definition to design a sustainable business model. Furthermore, (Heyes, Sharmina et al. 2018) applied eco-design into it to identify IT startups as a solution to sustainability in this realm. (Todeschini, Cortimiglia et al. 2017) developed an innovative circular business model in which the value propositions are sustainable and reduce environmental impacts. Through further case studies on innovative fashion startups, they identify their proposed concept an ideal one to accomplish the circular economy objectives. In another research, (Stål and Corvellec 2018) provide empirical evidence, based on seven case studies in Sweden, that businesses pro-actively looking for increase institutional demands for circularity to meet their own economic interests while that companies buffer their business model and their value proposition from emerging demands. 
Table 9. Circular economy

\begin{tabular}{ccccc}
\hline Author/s & Year & Contribution & Methodology & Data Source \\
\hline $\begin{array}{c}\text { (Heyes, Sharmina } \\
\text { et al. 2018) }\end{array}$ & 2018 & Framework & Qualitative & case study \\
$\begin{array}{c}\text { (Todeschini, } \\
\text { Cortimiglia et al. }\end{array}$ & 2017 & Framework & Qualitative & case study, interviews \\
2017) & & & \\
(Stål and Corvellec & 2018 & Empirical & Qualitative & \\
2018) & & &
\end{tabular}

\section{Sustainable business models in Third World countries cases}

(Vachani and Smith 2008) describes that sustainable business models are often researched in the develop countries where the real need for sustainable development in the third world countries. Nevertheless, sustainable business models in third world countries are highly needed to for creating values for both business and society. (Bittencourt Marconatto, Barin-Cruz et al. 2016) provides evidences for successful cases of sustainable business model in the third worlds. (Dembek, York et al. 2018) also provides a number of models to address the poverty while protecting the ecosystems. (Goyal, Sergi et al. 2017) study the strategic solutions to develop a sustainable business model in India. They propose a practical framework for creating a sustainable, scalable and socially relevant ecosystem. (Palomares-Aguirre, Barnett et al. 2018) study business models of three businesses that provide affordable housing with low environmental emissions.

Table 10. Sustainable business models in third word

Author/s Year Contribution Methodology Data Source

(Bittencourt Marconatto, $2016 \quad$ Empirical Qualitative interviews


Barin-Cruz et al. 2016)

(Goyal, Sergi et al. 2017)

(Dembek, York et al. 2018)
2017 Framework

2018

Framework
Evidences

Qualitative

secondary data

\section{Sustainable business model in civil engineering}

(Boo, Dallamaggiore et al. 2016) and (Moschetti, Brattebø et al. 2018) describe civil engineering as the biggest industry in the developed world with a high environmental impact. (Selberherr 2015) provides ideas on the sustainable service providing in this realm. He recommends that to design a sustainable business model taking the responsibility for the operating phase via guarantees should come to consideration. (Wasiluk 2013) further provids empirical evidences that local businesses though justifying the business case for sustainability they should concentrate on understanding how to mobilize their intellectual capital. Consequently, it will support them to enhance an ecological sustainable model. (Boo, Dallamaggiore et al. 2016) show that energy efficiency in construction of building is a serious matter in European countries. They consider sustainable business models as a solution to provide sustainability housing projects ensuring long-lasting change in the energy efficient building market.

Table 11. Civil Engineering

\begin{tabular}{ccccc}
\hline Author/s & Year & Contribution & Methodology & Data Source \\
\hline (Selberherr 2015) & 2015 & $\begin{array}{l}\text { Theoretical } \\
\text { Evidences }\end{array}$ & Qualitative & Literature synthesis \\
& & & & \\
(Wasiluk 2013) & 2013 & Empirical & Qualitative & Case study, interview
\end{tabular}


(Boo, Dallamaggiore et al. 2016)

\section{Sustainable business models in Tourism industry}

Tourism is considered as one the most important industries which have affected by sustainability movement. The research is done in the common field of business model sustainability and hotels are still in the infancy stage. (Buffa, Franch et al. 2018), utilizes a quantitative approach, provide empirical evidences that to introduce sustainable business models in this industry. They argue that these SMHEs adopted three different sets of environmental management practices (EMPs) to accomplish their sustainability goals of their business models. (Høgevold, Svensson et al. 2016) further compare the different between sustainable business models in manufacturing companies and truism industry. They believe that the nature of the industries is very effective in the models they have selected to meet the sustainability objectives.

(Melissen, Cavagnaro et al. 2016) shows that the current business models of hotel industry are not able to meet the sustainability objectives, especially with respect to addressing guests' needs and wants and (subsequent) institutionalization of sustainability. Nonetheless, they argue that managers' willingness and capabilities are potentially the sources stimulating them to transit toward a sustainable business model. (Høgevold and Svensson 2015) develop a sustainable business model for the hotels based on a case study they have conducted among a major Scandinavian hotel chain known for having implemented sustainable business practices within the company and in its business network.

Table 12. Tourism industry

Author/s Years Contribution Methodology Data Source

(Buffa, Franch et al.

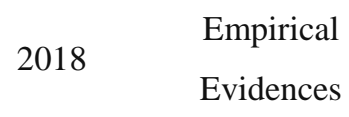

Quantitative

Questionnaire 


$\begin{array}{ccccc}\begin{array}{c}\text { Melissen, Cavagnaro et } \\ \text { al. 2016) }\end{array} & 2016 & \text { Empirical } & \text { Qualitative } & \text { Interviews } \\ & & \text { Evidences } & & \\ (\text { Høgevold, Svensson et } & 2016 & \text { Empirical } & \text { Qualitative } & \text { Case study } \\ \text { al. 2016) } & & \text { Evidences } & \end{array}$

\section{Biosphere reserves}

There is a gap in the research on using sustainable business models in biosphere reserves. However, there has been several researches on the urge to use such models to conserve the ecosystem while making sustainable profit. For instance, Jurjonas et al. (2016) presents an investigation on how moving toward unsustainable models can put in danger the biosphere reserves. In the following a number of relevant literatures has been identified where sustainability of local business has been considered in biosphere reserves.

Table 13. Sustainable business model in Biosphere reserves
Author/s
Year
Contribution
Journal

\begin{tabular}{|c|c|c|c|}
\hline & & Foraging for Meaning: Harvesting Wild Plants as the Basis for an & \\
\hline Giesting, K., & 2016 & Ecological Worldview & Master's thesis \\
\hline Jurjonas, & & Potential links between certified organic coffee and deforestation & World \\
\hline M., et al & 2016 & in a protected area in Chiapas & Development 78 \\
\hline Zebich- & & Ecotourism, park systems, and environmental justice in Latin & Environmental \\
\hline Knos, M & 2008 & America & justice \\
\hline Raufflet, E & 2008 & Innovation in business-community partnerships & $\begin{array}{c}\text { business in } \\
\text { society }\end{array}$ \\
\hline
\end{tabular}


Ernsteins, R 2012

Climate change adaptation integration into Coastal Municipal

Development

Reframing the sharing vs sparing debate for tropical forestry landscapes

Knaus, F., 2016

Lessons learnt from a monitoring endeavour in the UNESCO

Biosphere Reserve

Hong, S.
2015
Socio-economic foundation by biocultural resources management
Marine and Island

Cultures

\section{Lessons learned}

In above a comprehensive review on the various sustainable business models applications domains presented. Finding reveals that circular business models, are the major strategies have considered in the literature to design sustainable business models that is quite consistent. Often researchers consider designing a sustainable value proposition as an approach to design a sustainable business model. Innovative approaches have been presented in which customers are engaged in the designing process to devise a sustainable value proposition. The idea of using design thinking methods in the advancement of sustainable business model, developed the concept of value ideation to design a sustainable value proposition comprising additional values all stakeholders. Furthermore, the concept value shaping to develop financial, social and environmental value that a business creates by interacting with the different networks. Studying the role of change-makers is a topic that has considered in the common area of literature of business and management and business model sustainability.

Here is worth mention that the role entrepreneurship is underrepresented particularly in advancing the environmentally sustainable startups. Much research is conducted on developing solutions for sustainable models to manage the resource and the 
energy to provide sustainable value propositions. We believe that the traditional business models in number of big industries industry produce highly negative outcomes for the environment. Therefore, sustainable business models for smaller sized business would be of great advantage to address the need of low-incomes. On the other hand, creating value for the customer and environmental and capturing value for the small firms is the solution to eliminate the barriers in transition of traditional supply chain toward a slowing and a closing loop of resources. Consequently, achieving sustainability goals would be achievable through small communities with a great motivation. Also, in many cases the key success to business model sustainability would be digital technology where utilizing the mobile technology can design a diverse sustainable business model for profit making. Such novel technologies reduce the use of raw material and waste generation. Finding exposes that the Bottom of pyramid has centered in the hotspot of designing SBMs in in develop countries.

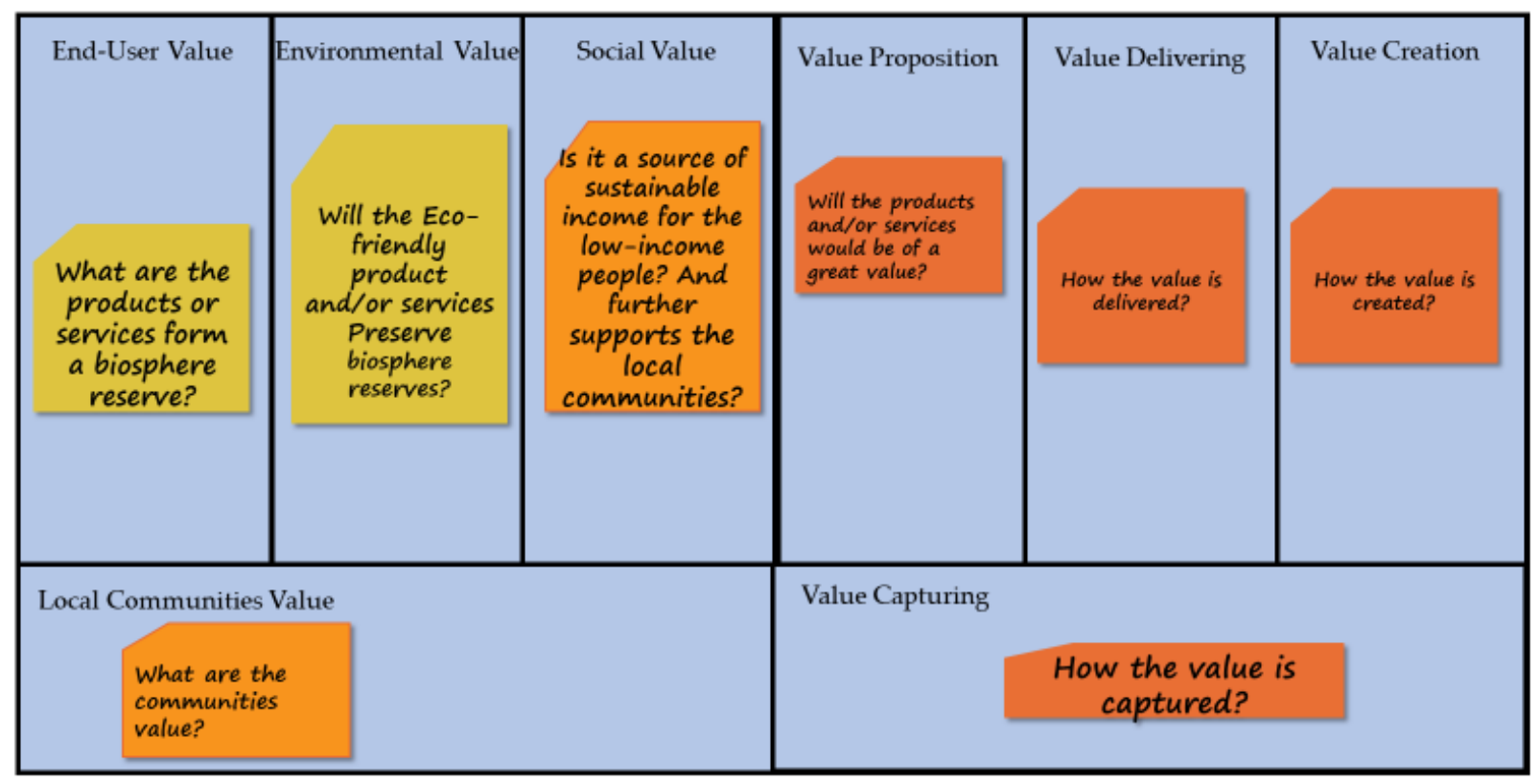

Figure 3. Characteristics of a sustainable business model for biosphere reserves: questions to be answered

Illustrating the research path and articulating in detail the application of sustainable business model the ecosystems preserving aspects including biosphere reserves 
provide insights and the possibility of compressions for both practitioners and researchers who are eager to find sustainable solutions through. Designing or advancing a sustainable business model can be achieve through value proposition which is able to provide values to multi-stakeholders such as society and environment while it can be profitable for the local communities. Sustainable value creation and value delivering are other solutions have emerged in developing a reliable sustainable business model. As the result of the lesson learned figure 3 illustrates a sustainable business model that we should look for it in biosphere reserves.

This model has 8 components to be discussed including: Social Value Environmental Value, End-User Value, Value Proposition, Value Delivering, Value Creation, Value Capturing, and Local Communities Value. For that we should answer the following questions respectively.

- What are the products or services form a biosphere reserve?

- Will the Eco-friendly product and/or services Preserve biosphere reserves?

- Is it a source of sustainable income for the low-income people?

- And further supports the local communities?

- Will the products and/or services would be of a great value?

- How the value is delivered? How the value is created?

- What are the communities value? How the value is captured?

During the field trips to the biosphere reserves, we have in mind these 8 question to be answered while considering local businesses for sustainable business models. 


\section{Section 2: Sustainable business Models in Biosphere Reserves of Hungary}

Through the lessons learned from the last section on the sustainable business models, in this section through action research several potential business models are examined. Via qualitative research methods and interaction with locals within various biosphere reserve zones sustainability of business models has been considered.

\section{Biosphere Reserves in Hungary}

Hungary joined the MAB Programme as one of the first countries in the late 1970. Prof. János Balogh initiated the movement. As the result, within 1979-1980 four Hungarian biosphere reserves were nominated and designated which were first generation of the type to motivate the international movement on the protection and scientific research of ecosystems. This has been a new focus toward valuing the interactions between man and nature, in other words "Man and Biosphere" MAB. According to the Hungarian Act on Nature Conservation the core zone is strictly protected area and any business activities are not allowed. This has been one reason that we more focus on the buffer zones and transition zones where human activities are allowed.



Figure 4. Biosphere Reserves in Hungary (Photo credit: http://www.termeszetvedelem.hu) 


\section{Sites of the study}

kiskunság biosphere reserve and Pilis biosphere reserve have been selected as the sites of the studies and the field trips. Through field trips various business models are considered from for satisfying the goals of a sustainable business model. Both Biospheres reserves within their three zones involve various businesses including the hospitality, truism, cultural activities however they often don't fully satisfy the ideal sustainable business model goals. Field trips bring a great insight on the further possible models for sustainability which also brigs value.

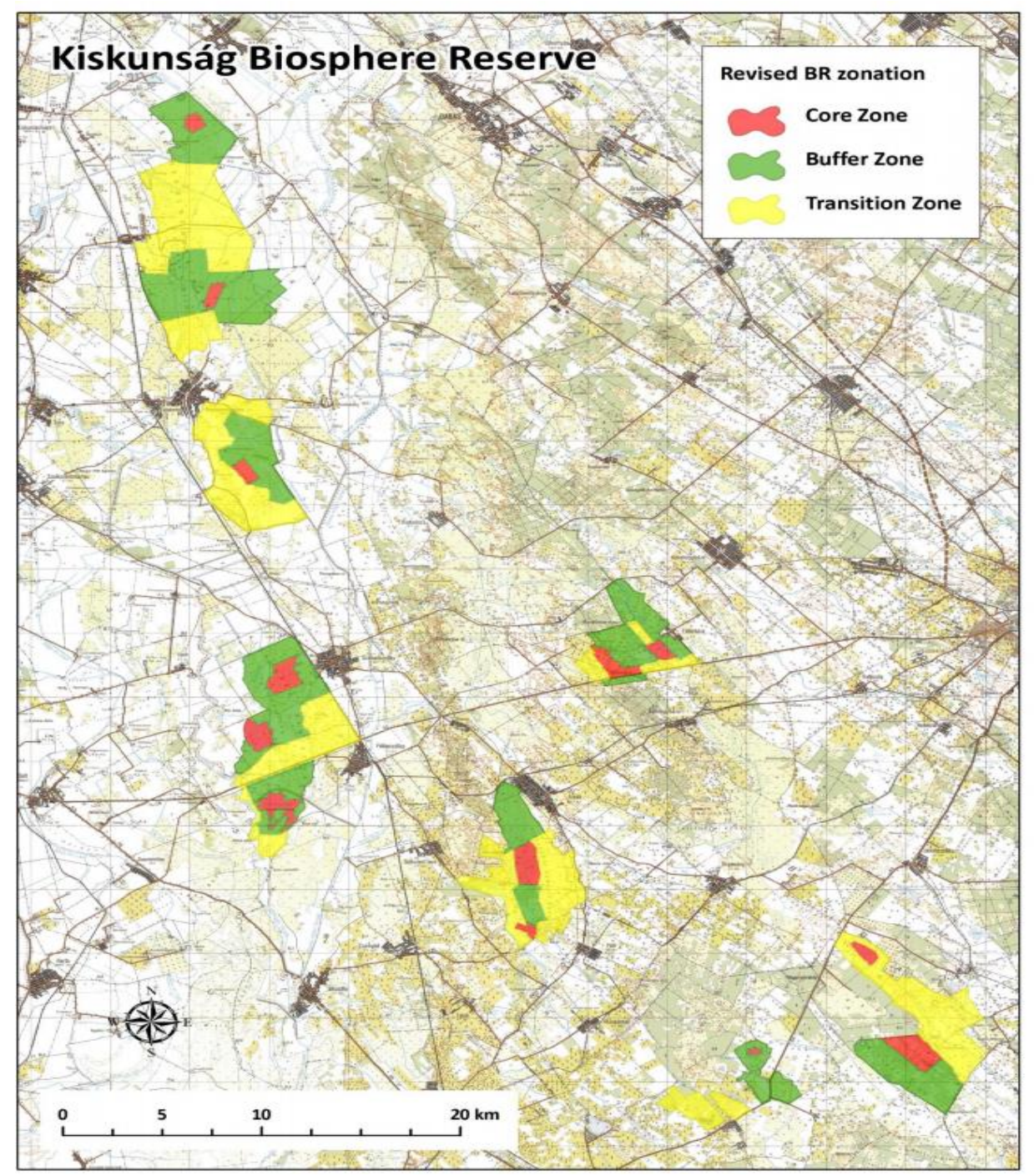

Figure 5. kiskunság biosphere reserve (Photo credit: $h t t p: / / w w w . t e r m e s z e t v e d e l e m . h u$ ) 


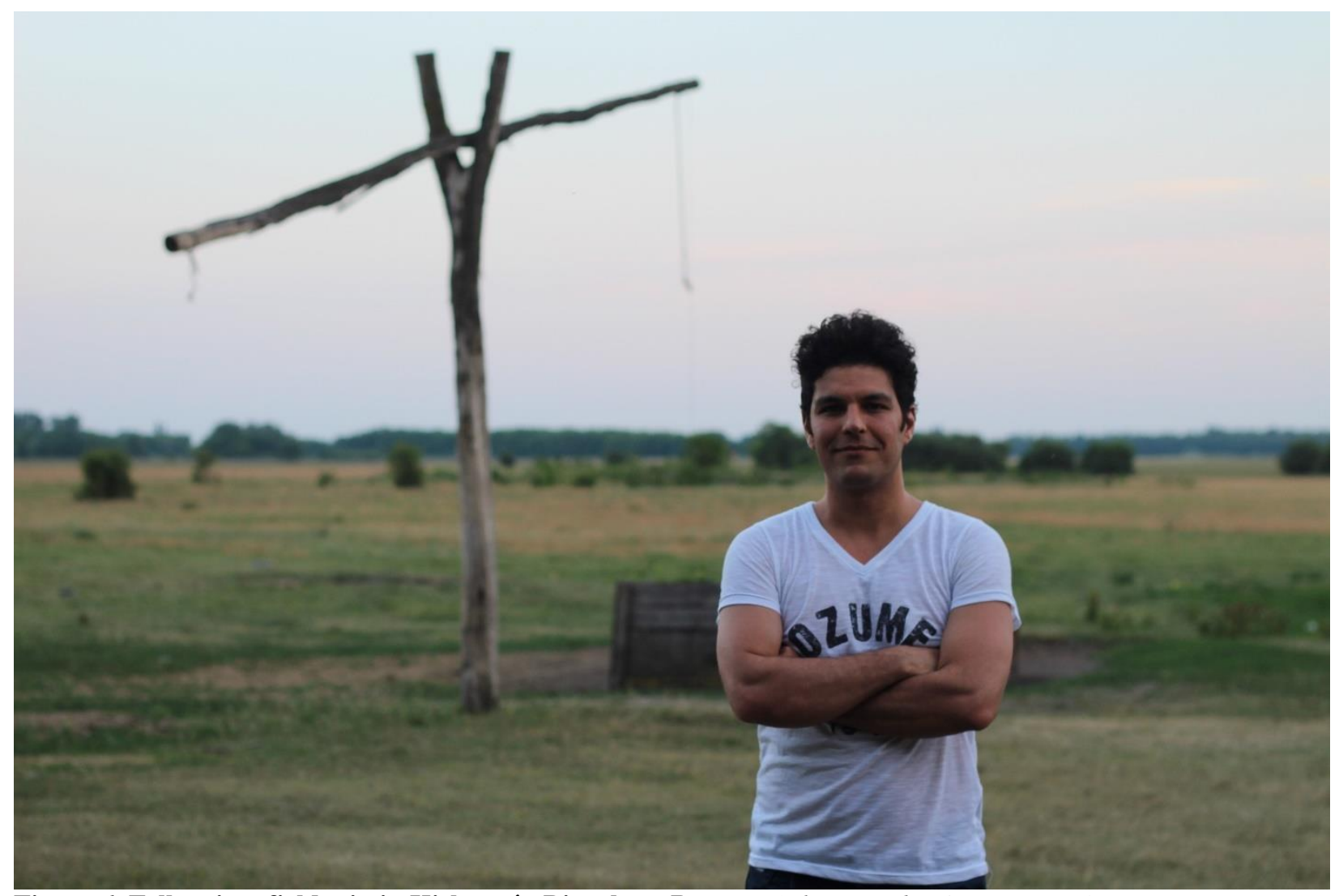

Figure 6. Fellow in a field trip in Kiskunság Biosphere Reserve (Photo credit: Amir Mosavi)

The Kiskunság Biosphere Reserve as one of the warmest region of Hungary is of priority importance with regard to conservation of biological diversity in the Pannonian Biogeographical Region. Its territory are wetlands and several Natura 2000 sites under the EU Birds Directive and Habitats Directive since 2004. Furthermore, the Izsák and Kolon-tó are the Biogenetic Reserves. The diverse habitat mosaics support a rich flora for several species endangered species. The region benefits from a temperate continental climate with limited cloud cover, dryness and numerous sunny hours, and high annual temperature variation. Although the core zone size of Kiskunság Biosphere Reserve is around 2,275 ha, for our study we explored the surrounding region which involves numerous farms and planted forests. 


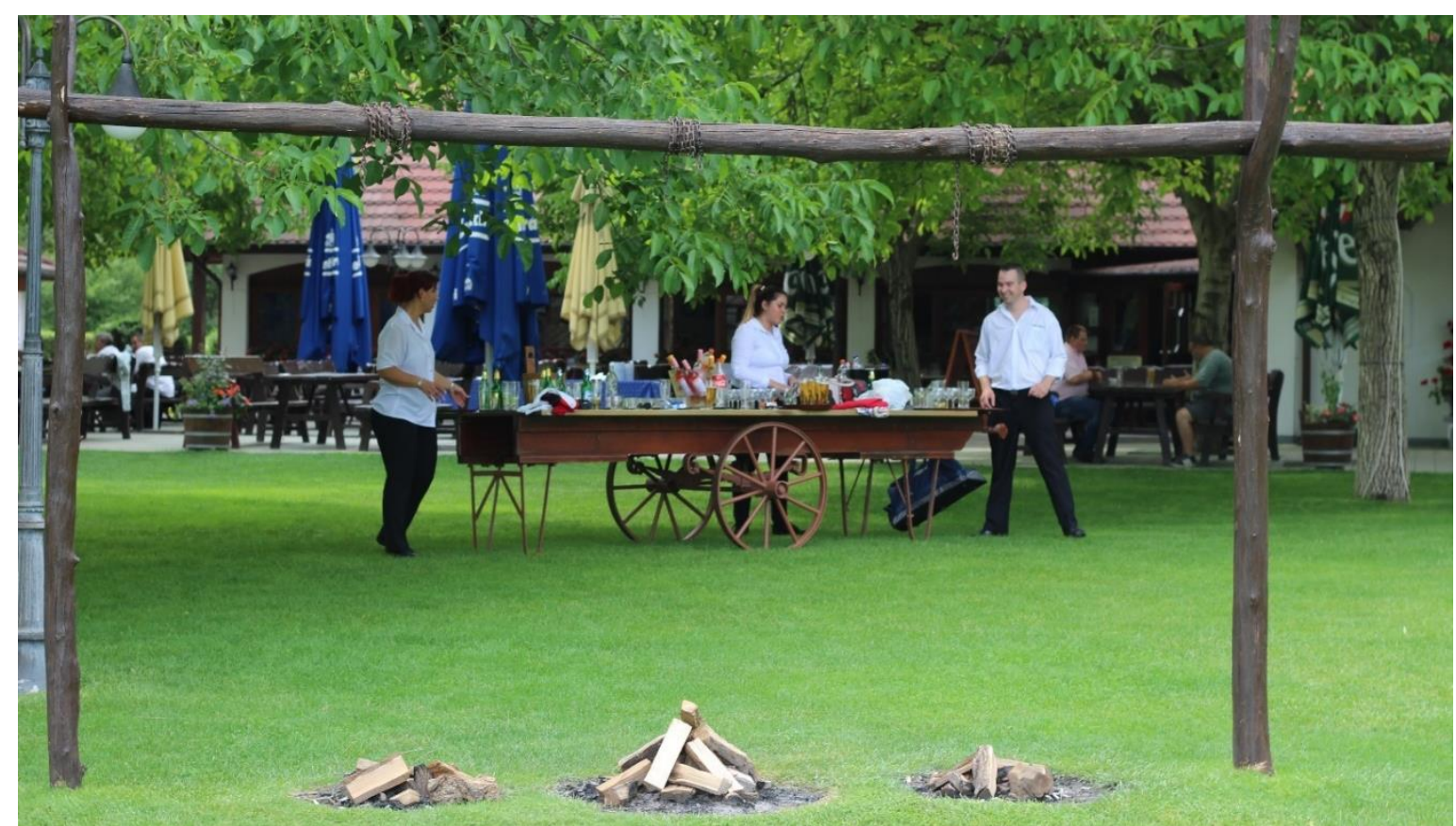

Figure 7. Numerous hospitality business around the Kiskunság Biosphere Reserve, a local hotel (Photo credit: Amir Mosavi)

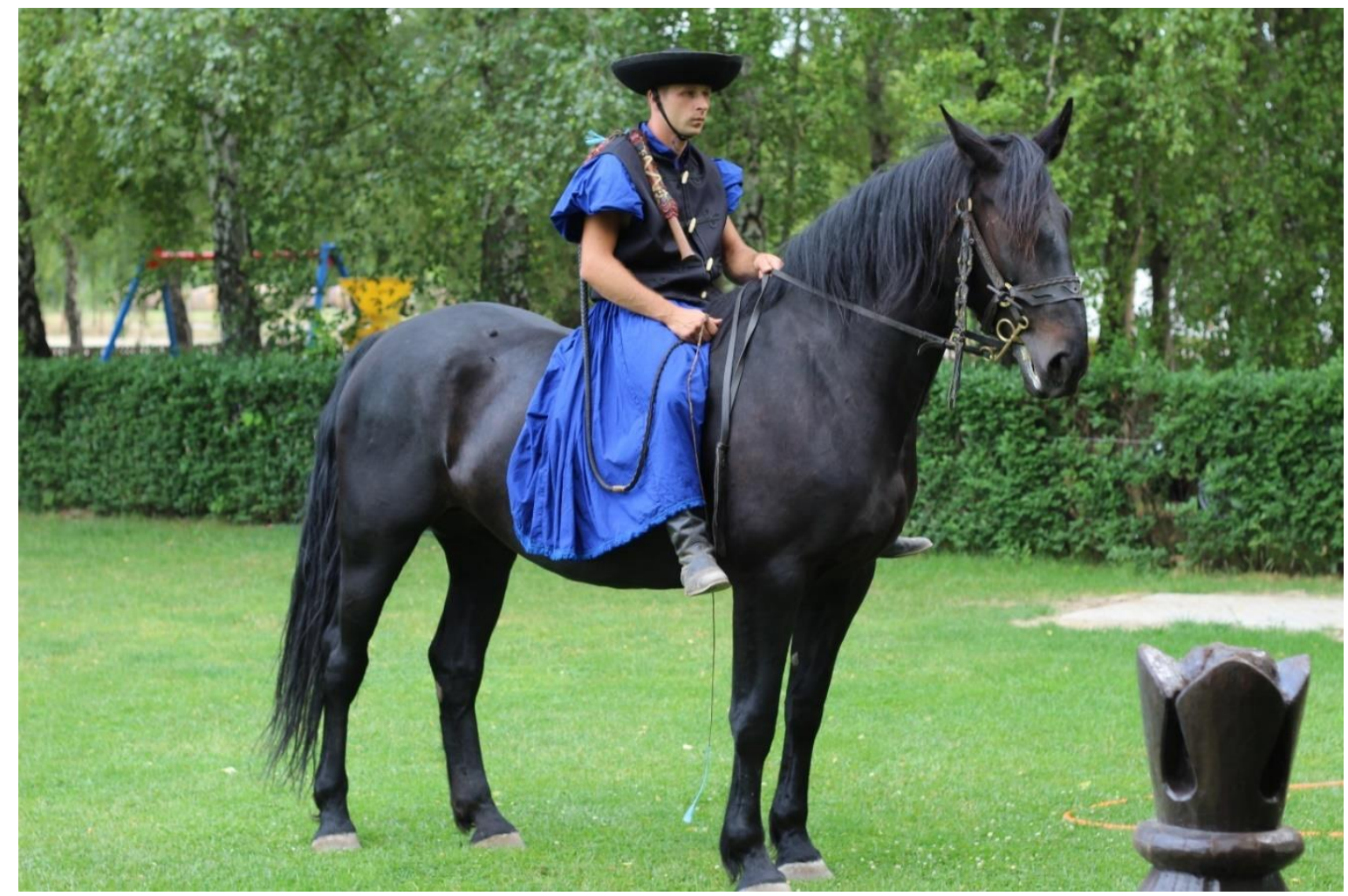

Figure 8. Tanya: Hungarian farm for hospitality and horse shows, Kiskunság Biosphere Reserve (Photo credit: Amir Mosavi) 


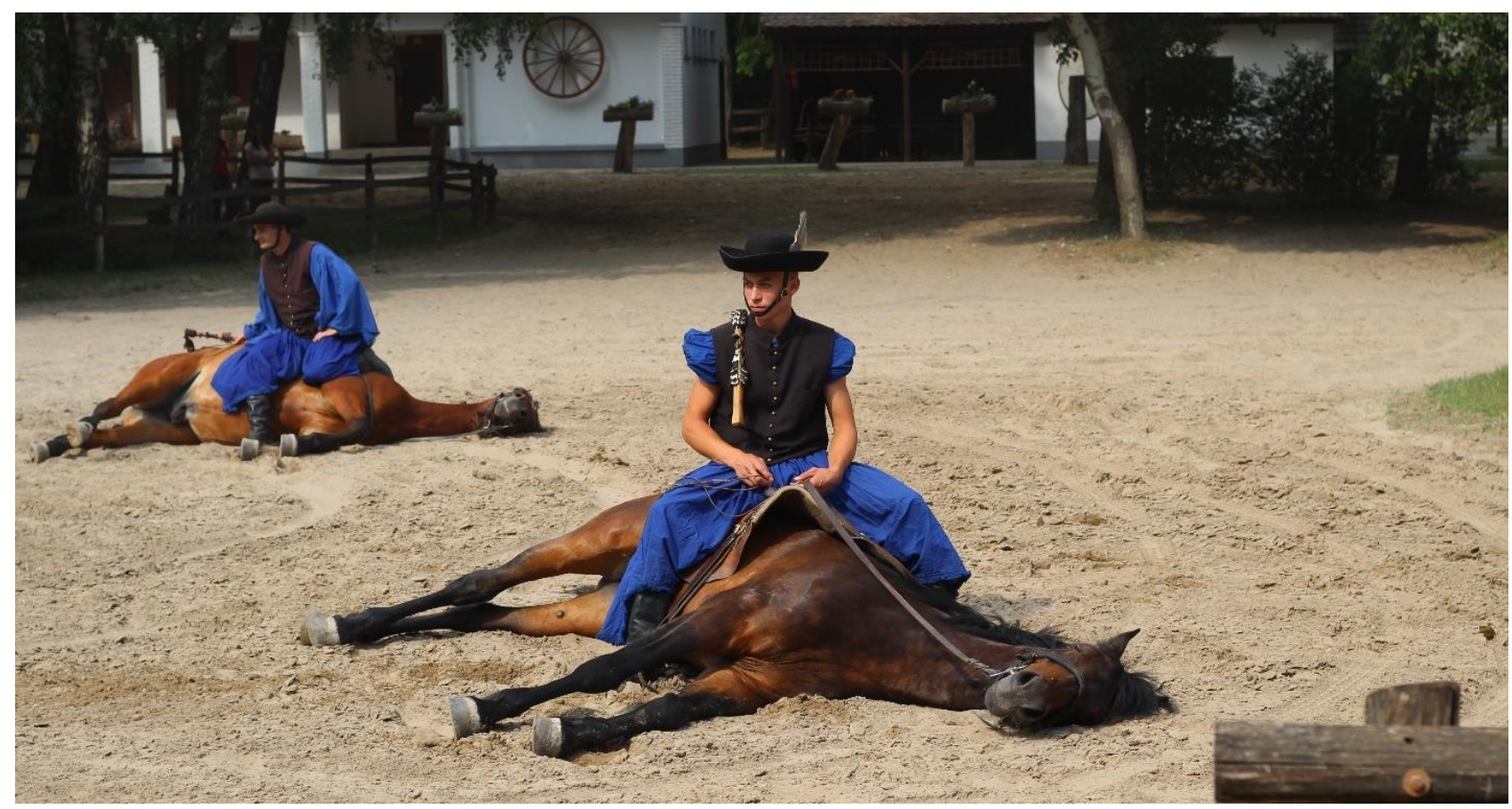

Figure 9 Tanya: Hungarian farm for hospitality and horse shows, Kiskunság Biosphere Reserve (Photo credit: Amir Mosavi)

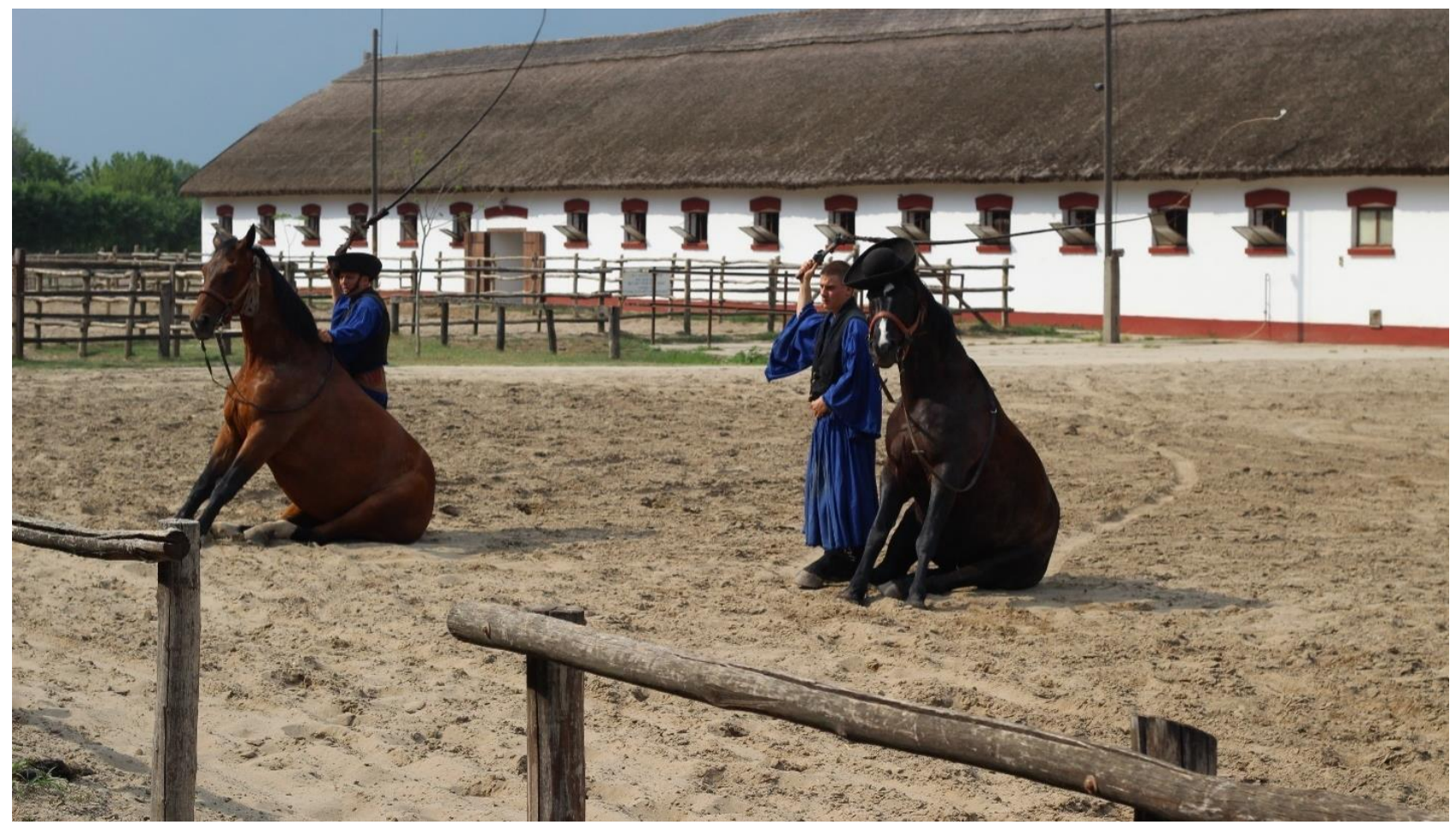

Figure 10. Tanya: Hungarian farm for hospitality and horse shows, Kiskunság Biosphere Reserve (Photo credit: Amir Mosavi) 


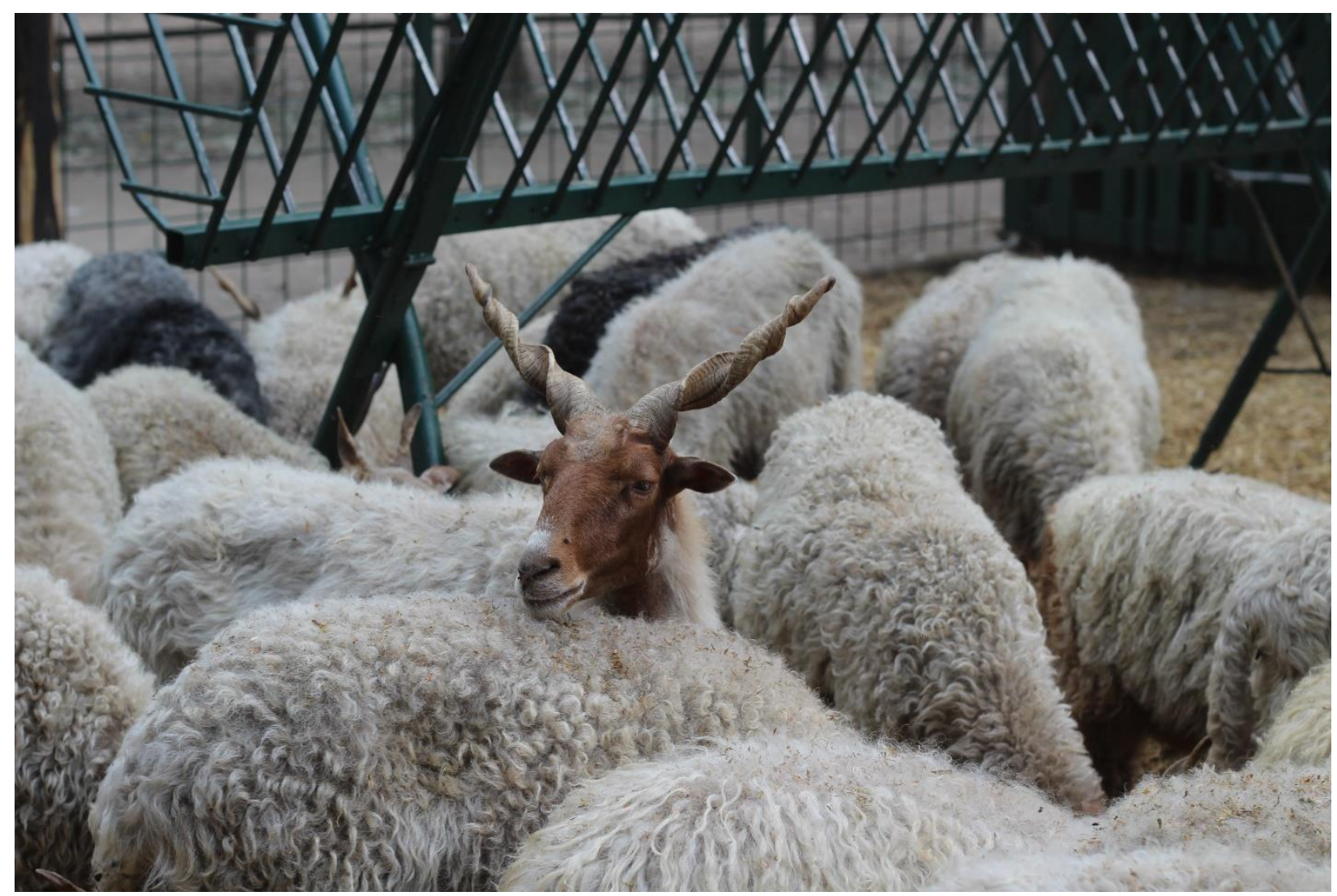

Figure 11. Tanya: Hungarian farm for livestock farming, Kiskunság Biosphere Reserve (Photo credit: Amir Mosavi)

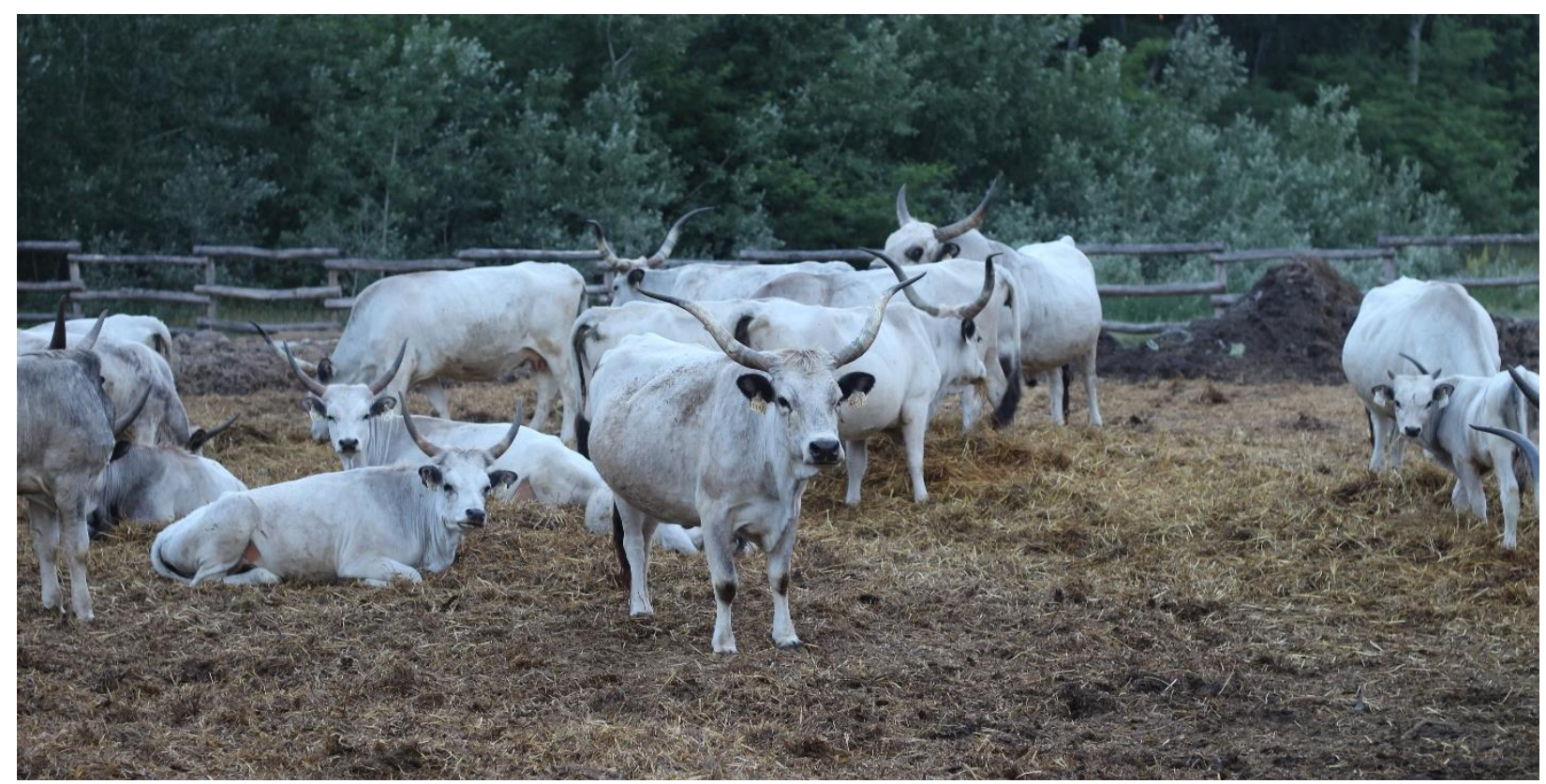

Figure 12. Tanya: Hungarian farm for livestock farming, Kiskunság Biosphere Reserve (Photo credit: Amir Mosavi) 


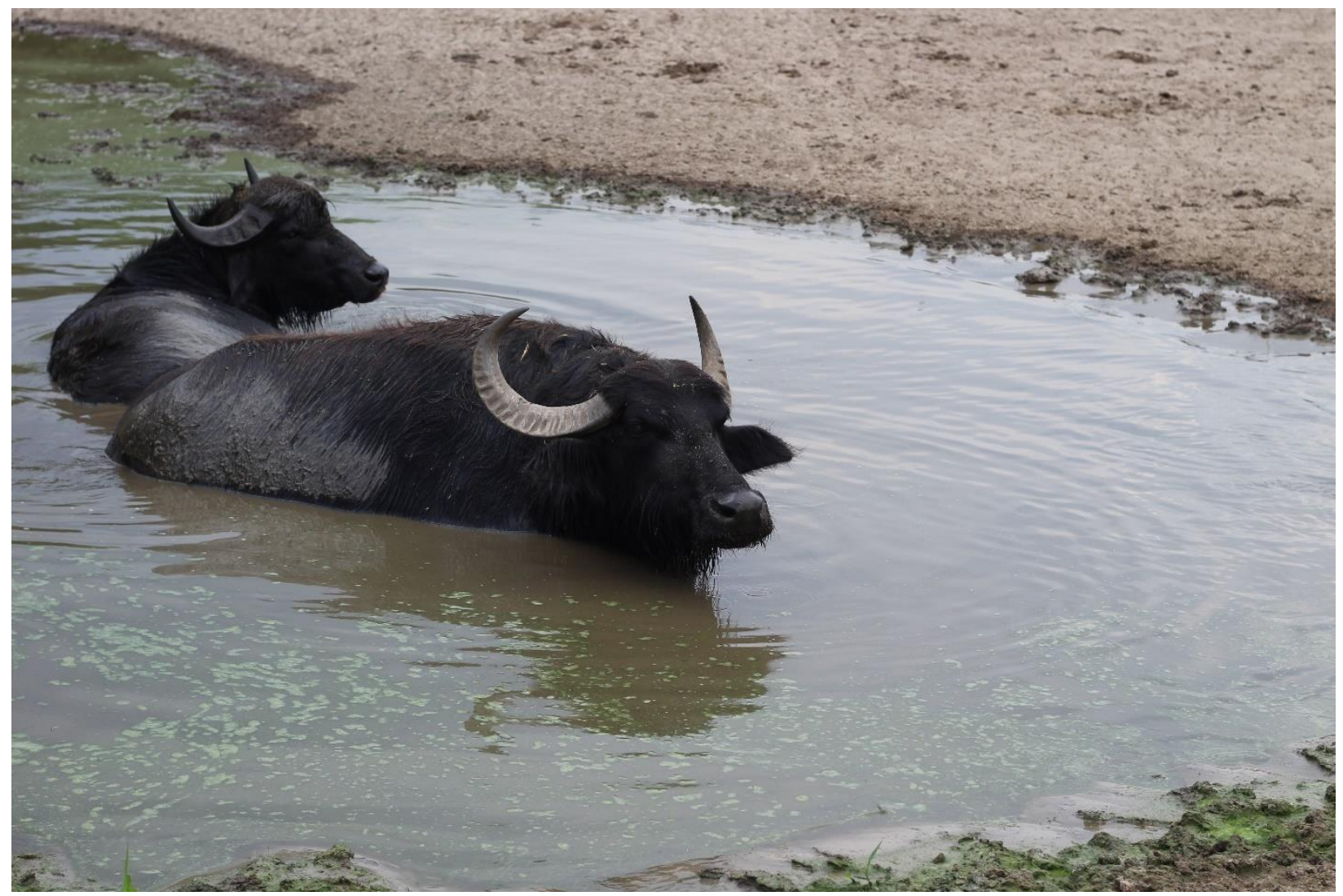

Figure 13. Tanya: Hungarian farm for livestock farming, Kiskunság Biosphere Reserve (Photo credit: Amir Mosavi)

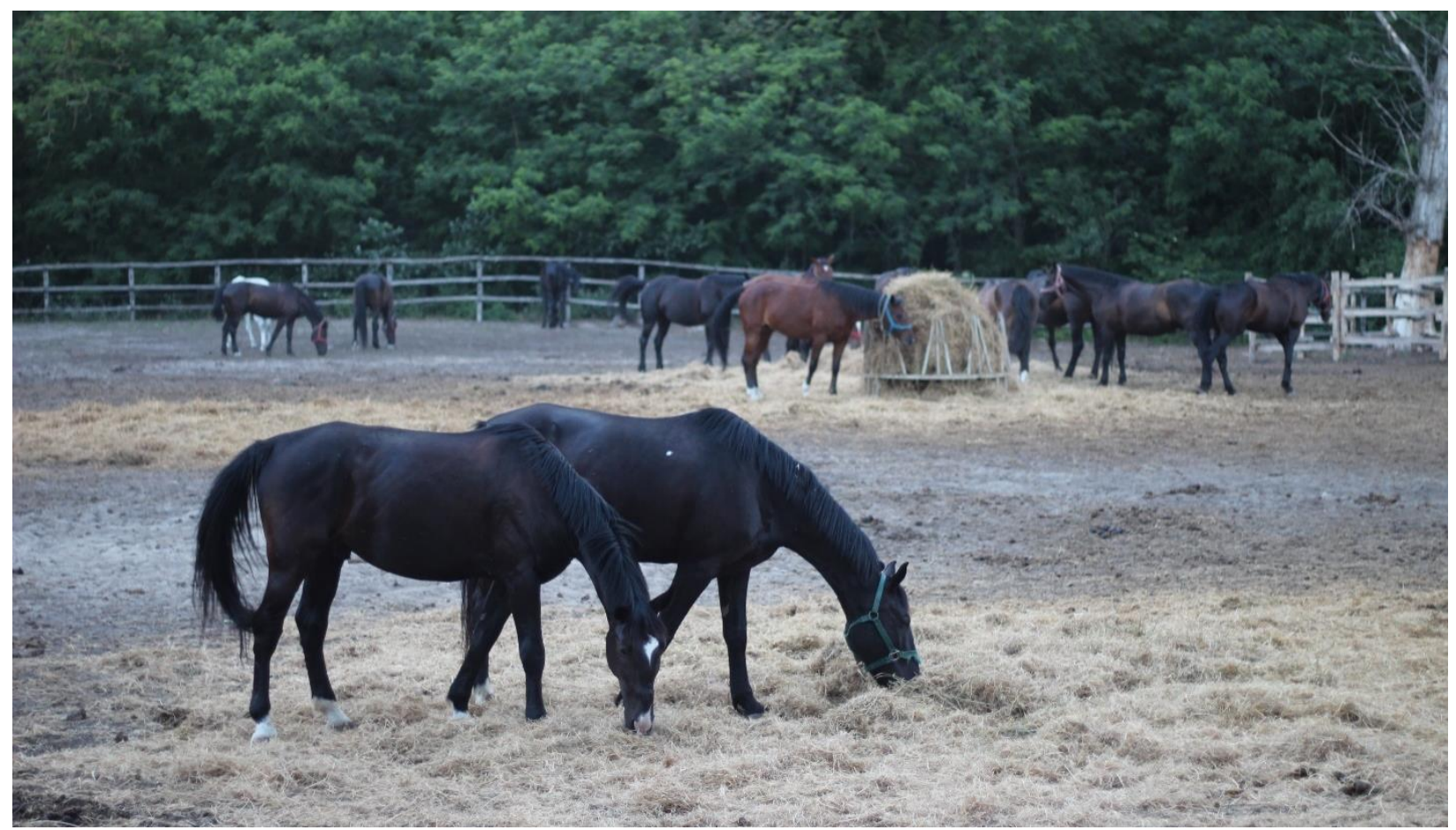

Figure 14. Farms around the Kiskunság Biosphere Reserve are widely involved with businesses connected with horse, from breeding to show (Photo credit: Amir Mosavi) 


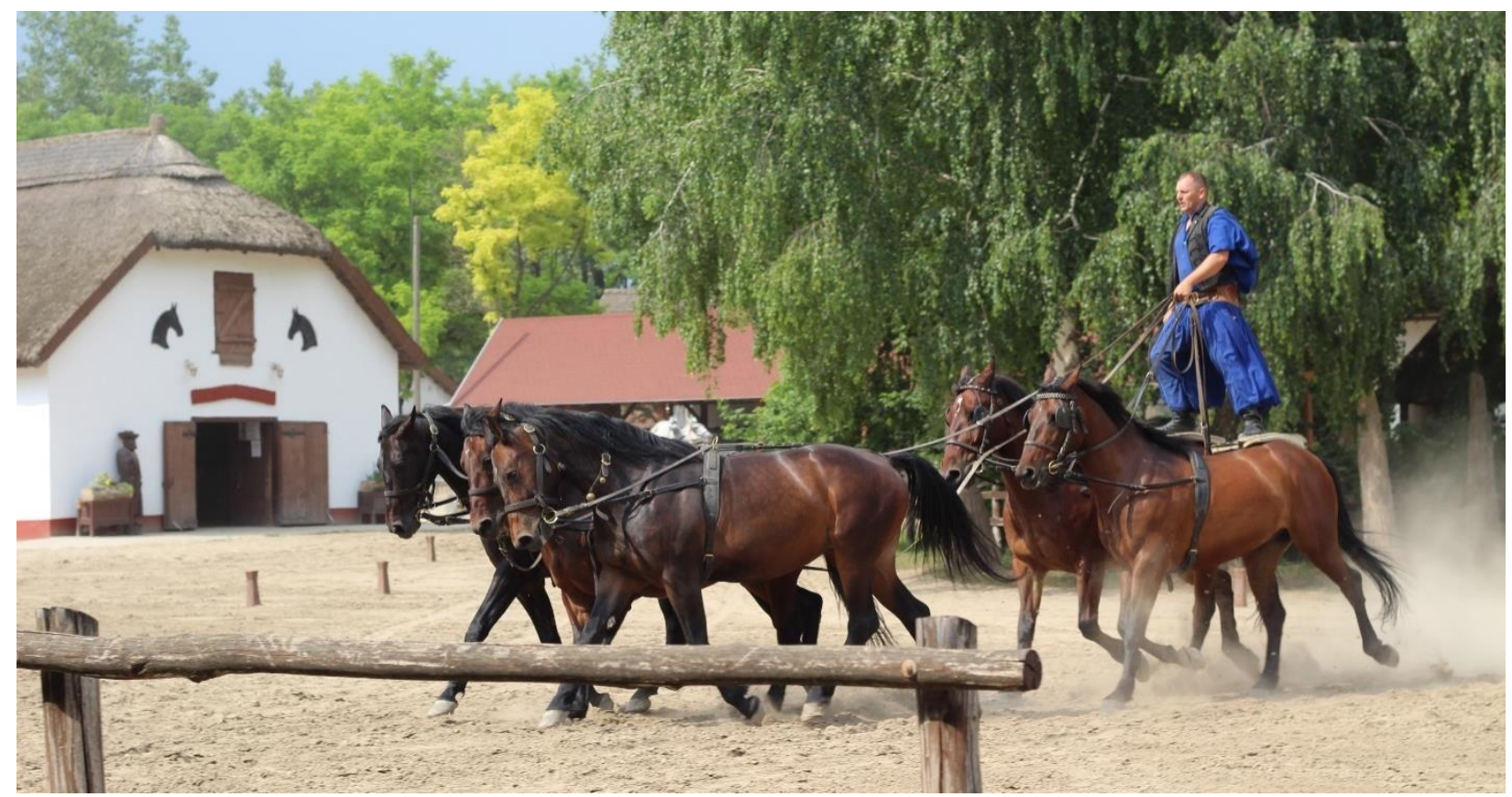

Figure 15. Farms around the Kiskunság Biosphere Reserve are widely involved with businesses connected with horse, from breeding to show (Photo credit: Amir Mosavi)

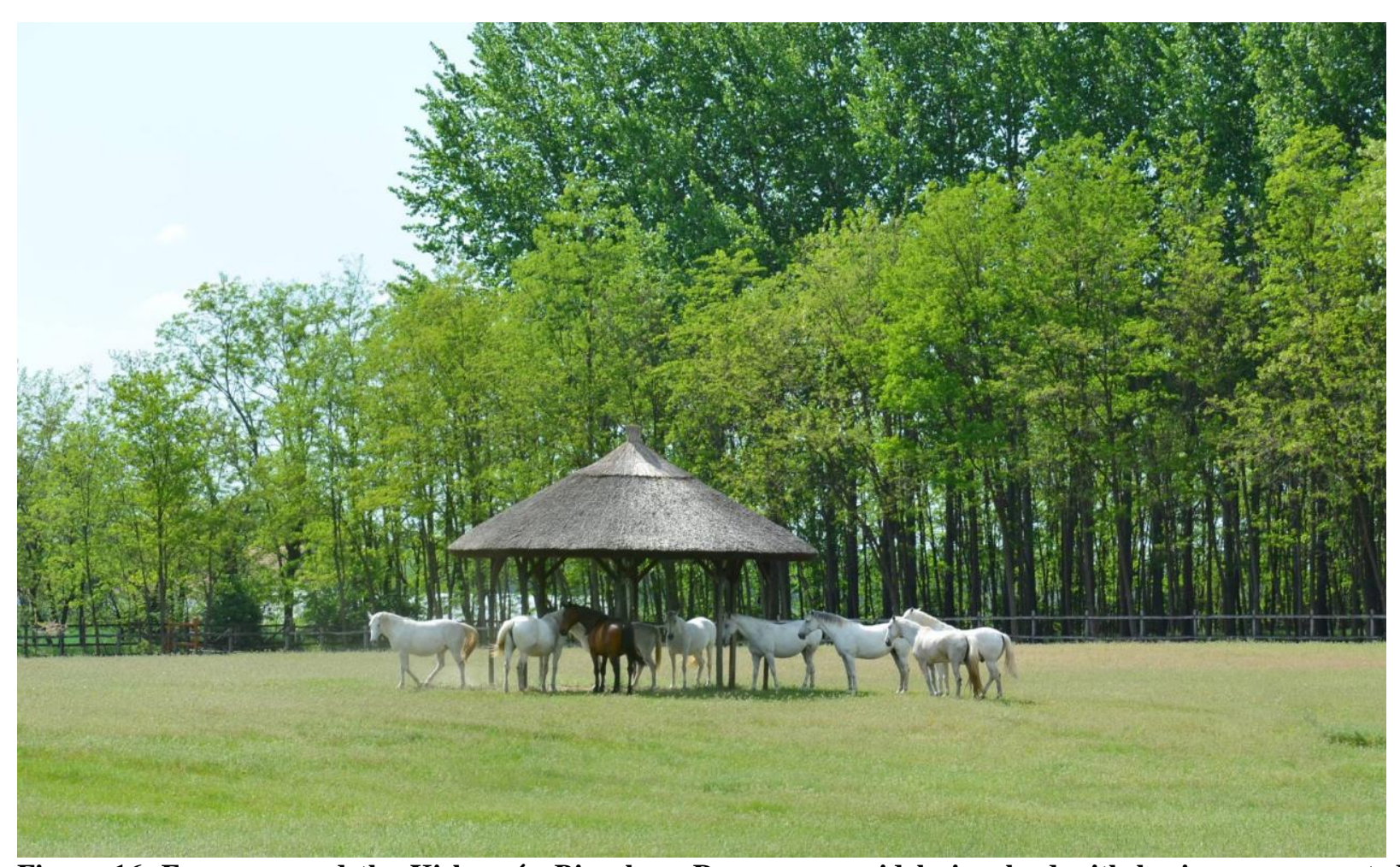

Figure 16. Farms around the Kiskunság Biosphere Reserve are widely involved with businesses connected with horse, from breeding to show (Photo credit: WWOOF Hungary) 


\section{Pilis Biosphere Reserve}

Pilis Biosphere Reserve with a unique diversity locates on the northwest of Budapest along the U-turn of Danube river. This reserve is the home to several plants and animals which makes an ideal site for environmental education. Ecosystem conservation in Pilis brings a great deal of advantages for environmental education of the local young generation.

In Pilis the region of Szamárhegy és Kerektó is the home of a variety of rock and steppe vegetation in addition to brush-forests, and dry oak-forests. And Vaskapuhegy and Nyírvölgy includes plains plant species and wild grape varieties respectively.

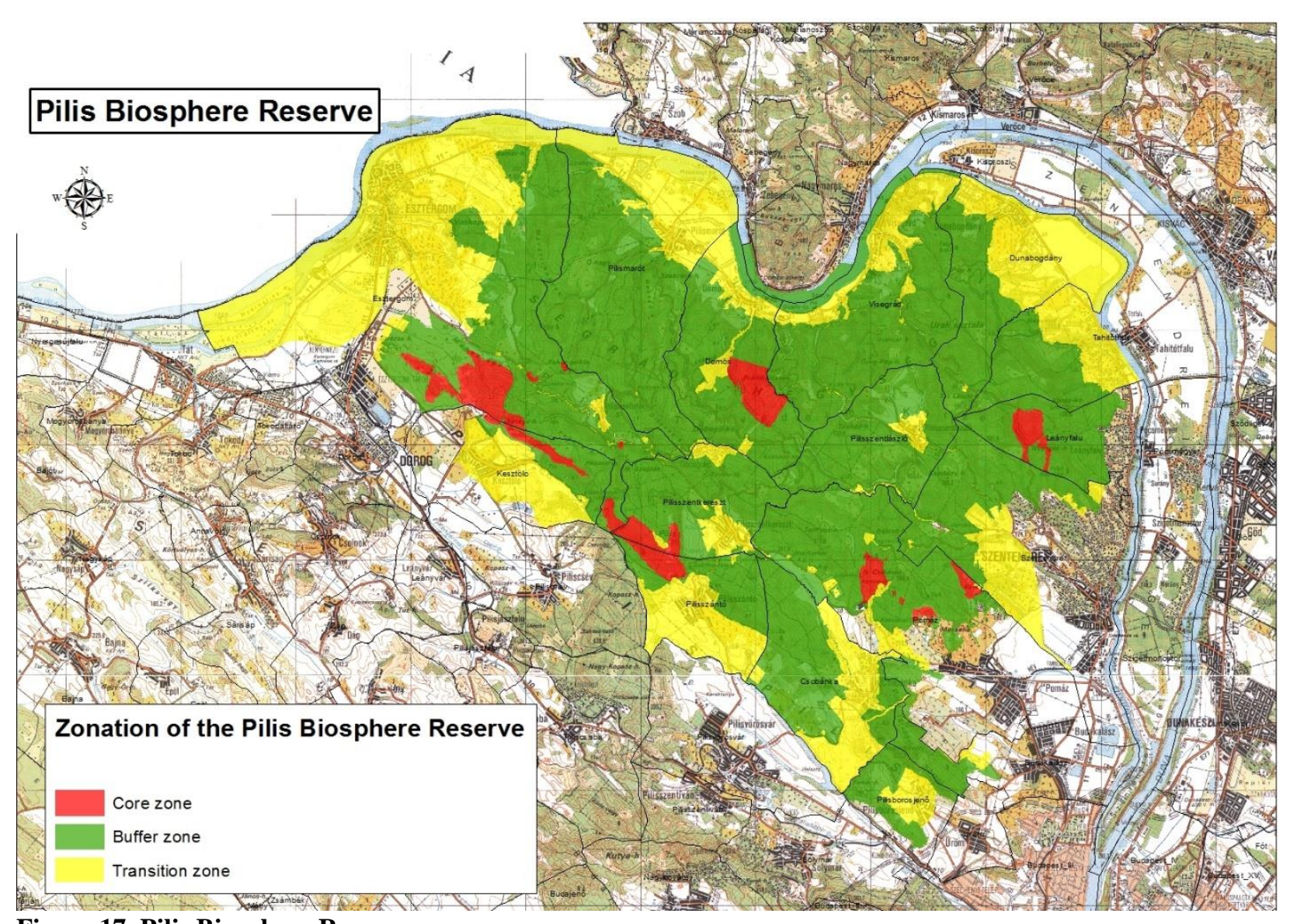

Figure 17. Pilis Biosphere Reserve 


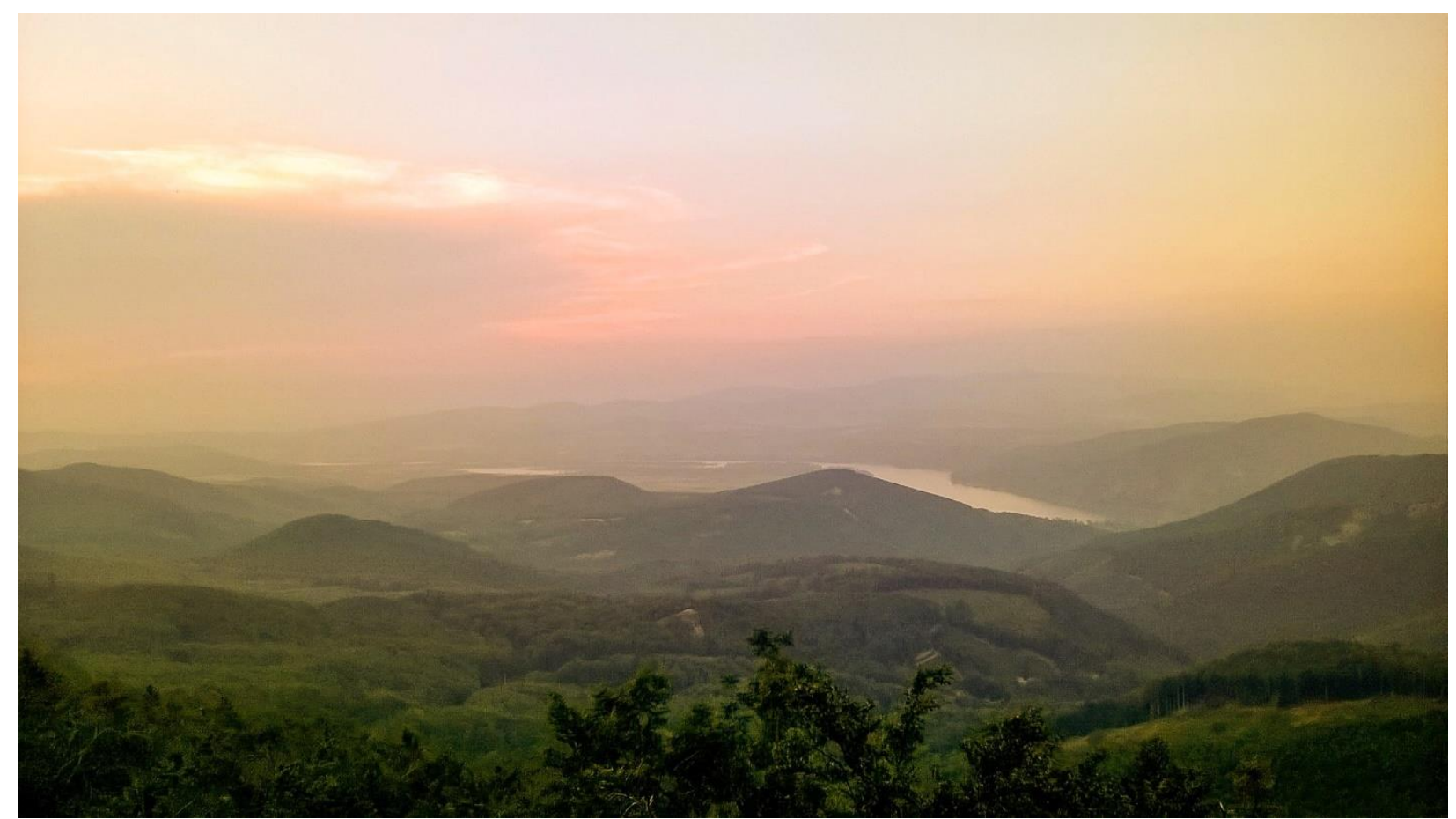

Figure 18. Field trip in Pilis Biosphere Reserve (Photo credit: Amir Mosavi)



Figure 19. Fellow on field trip in Pilis Biosphere Reserve, looking for foragers (Photo credit: Amir Mosavi) 




Figure 20. Pilis Biosphere Reserve (Photo credit: Amir Mosavi)

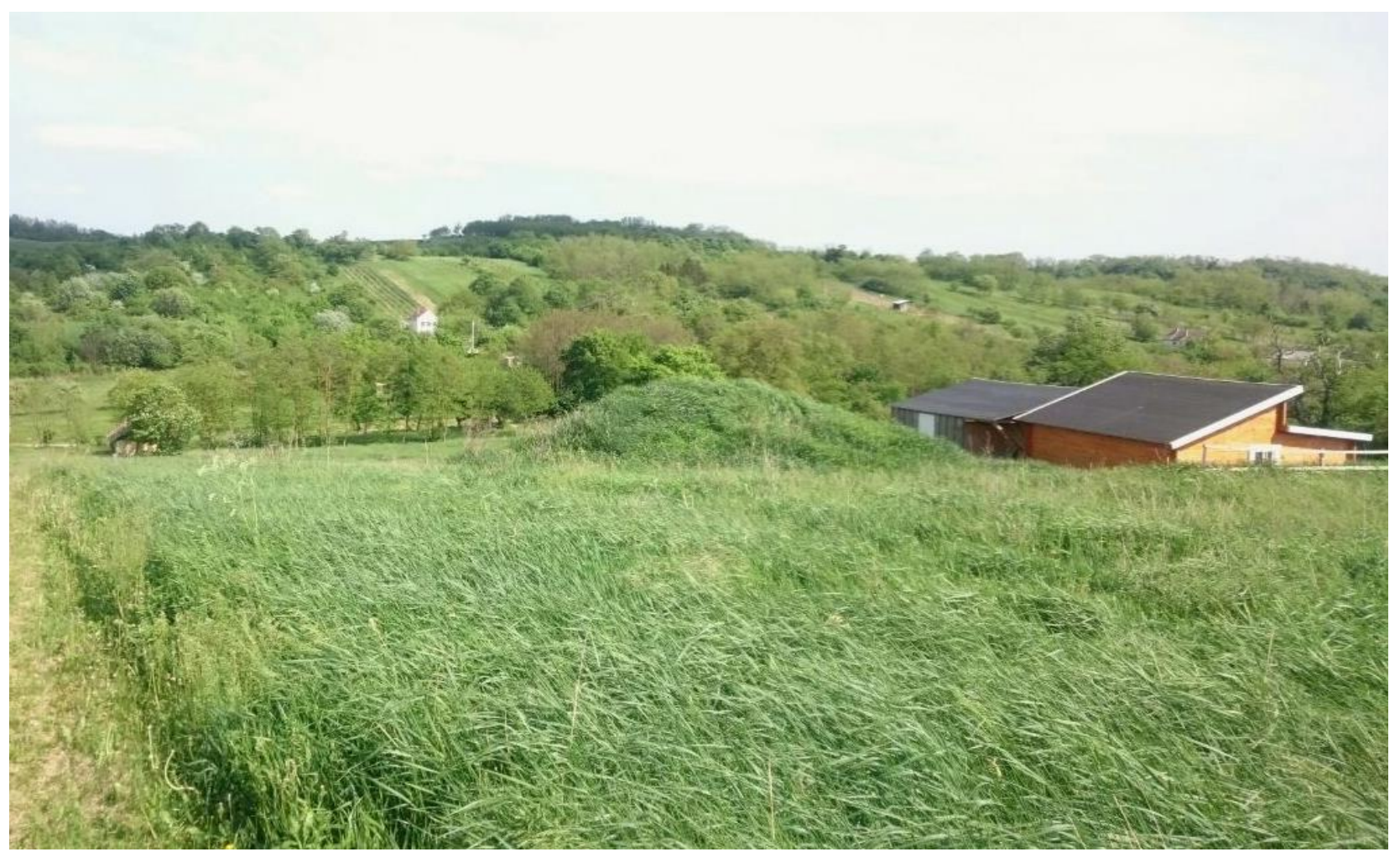

Figure 21. Pilis Biosphere Reserve (Photo credit: Amir Mosavi) 


\section{Studying foraging as the sustainable business model}

During the field trips various business models came to the considerations. However, this research found the "foraging for tea making" can fully answer the 8 questions regarding a sustainable business model. This has been a great motivation to further explore this business model.

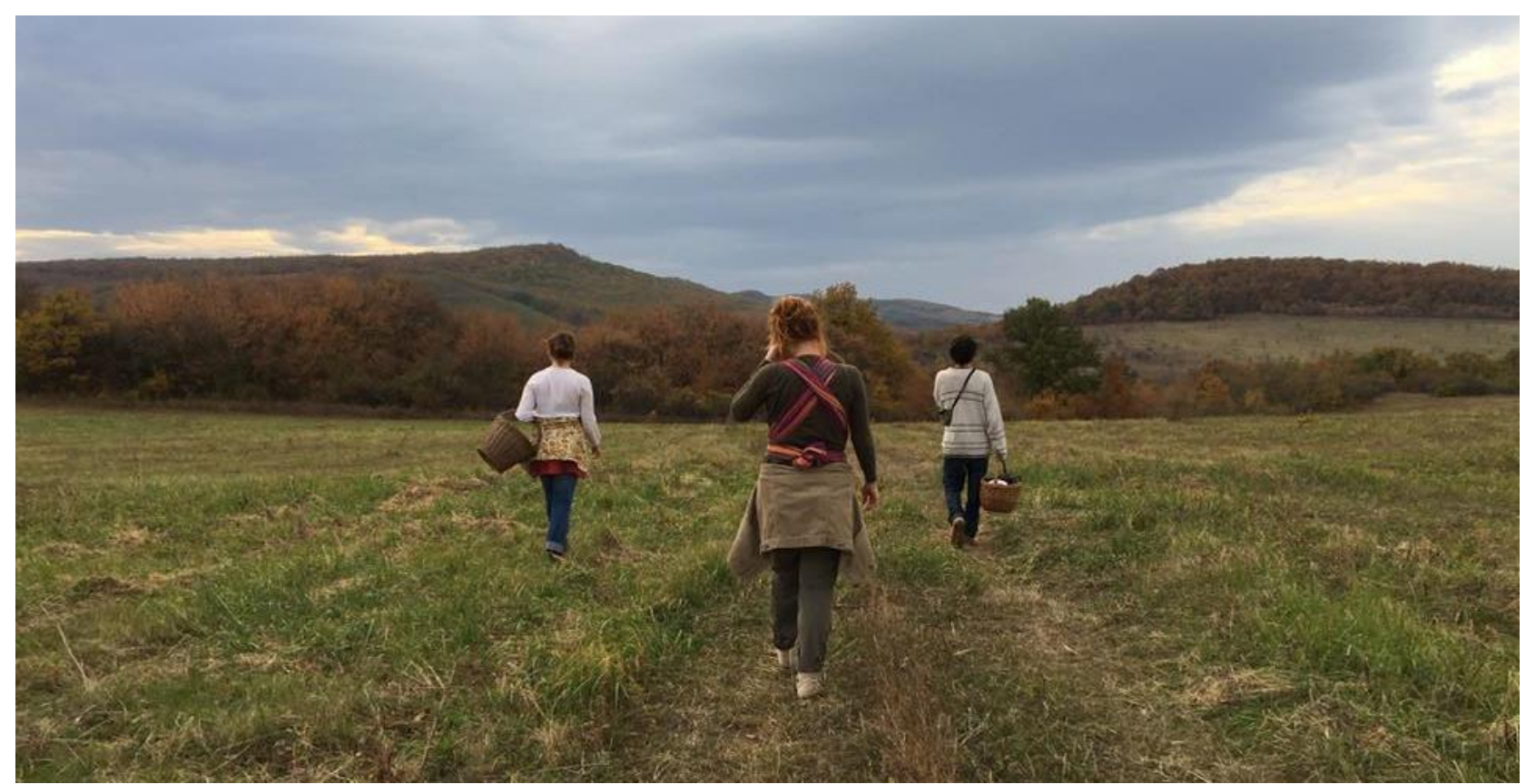

Figure 22. Foraging (Photo credit: Dániel B. Kovács)
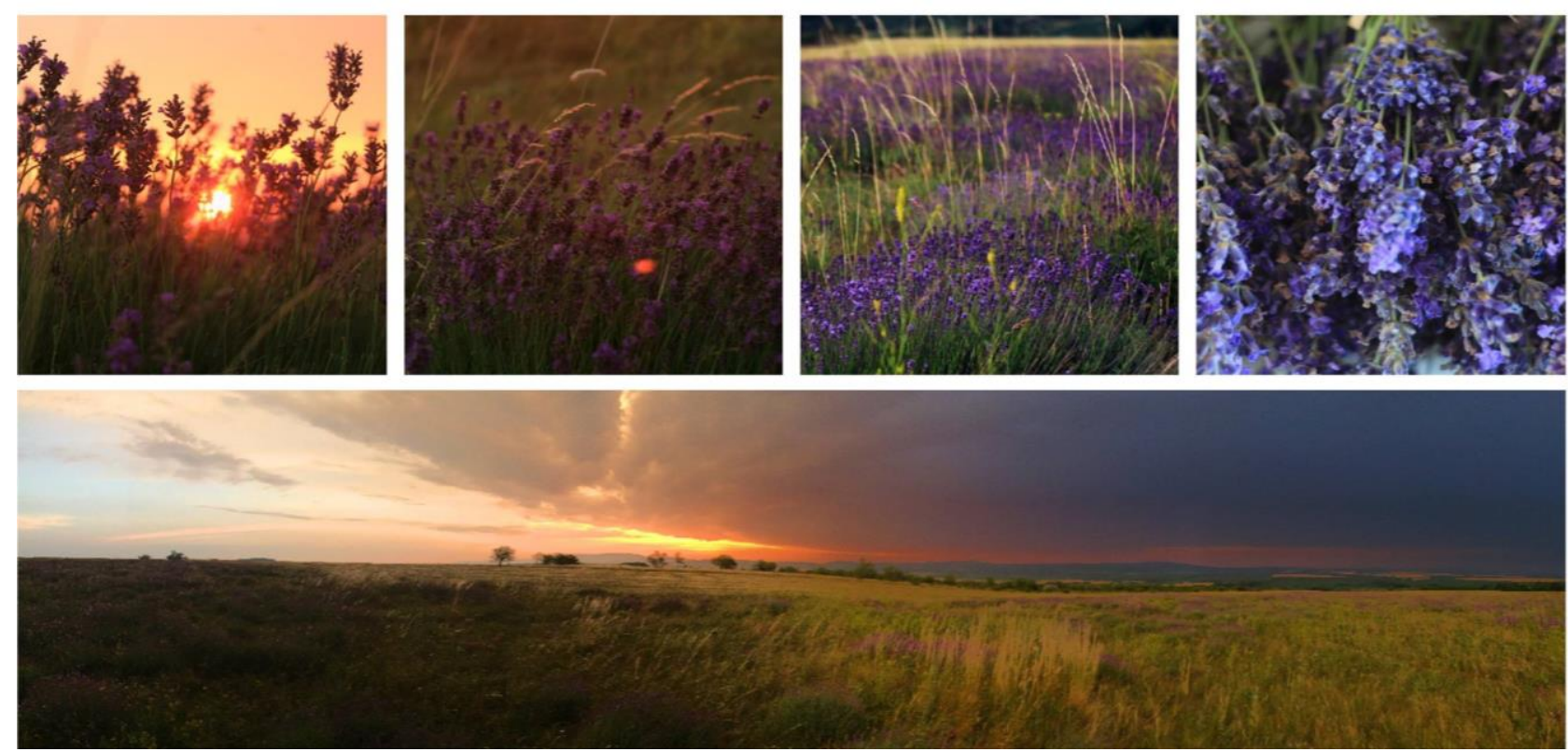

Figure 23. Foraging, the potential sustainable business model of Biosphere Reserves (credit: Dániel B. Kovács) 


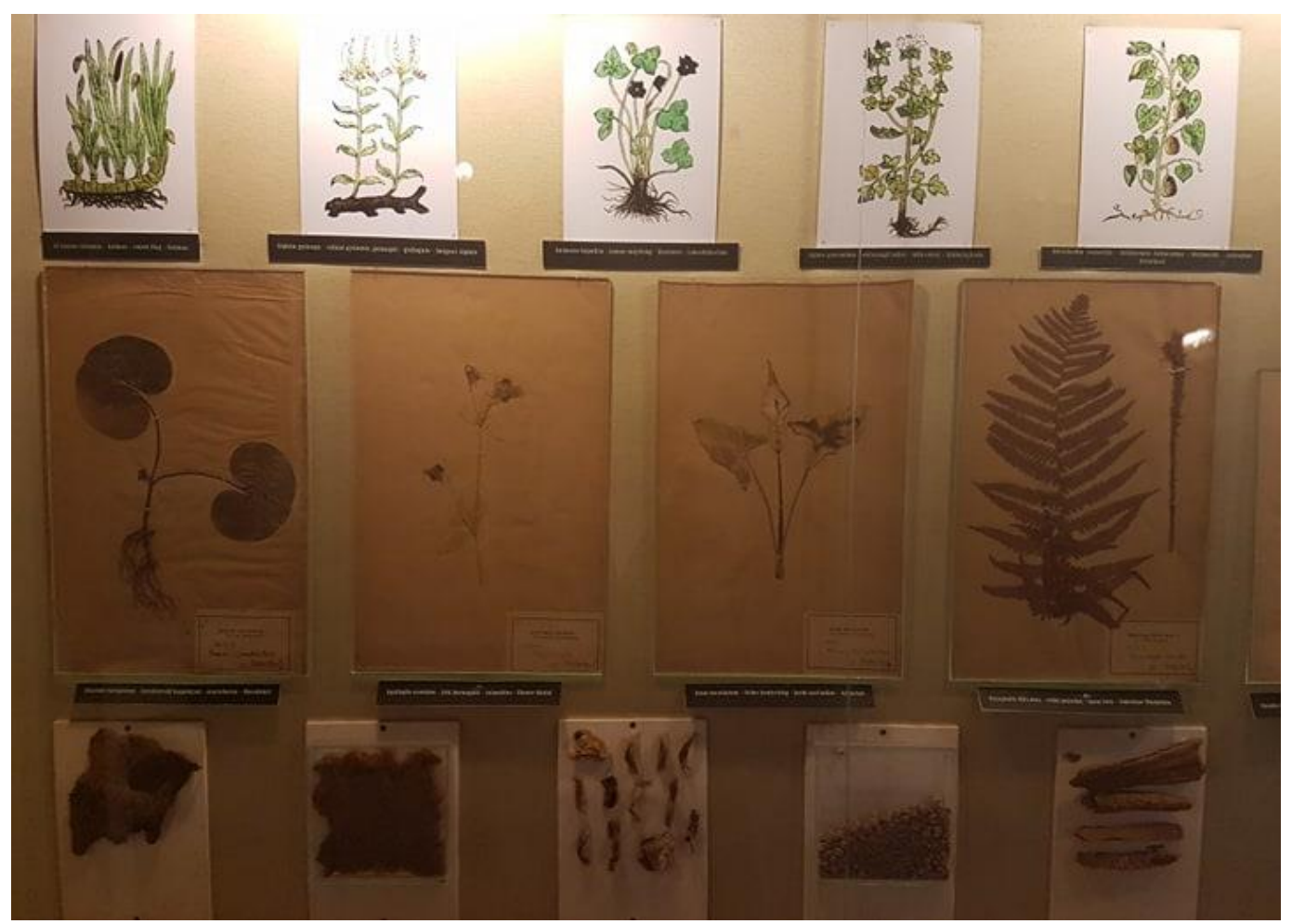

Figure 24. there are more than 50 plants species which can be foraged sustainably in region (Photo credit: Amir Mosavi)

\section{Methodology}

To study the foraging, I used both qualitative and quantitative approaches in order to investigate the process of foraging as a business and further evaluate the values and beliefs of foragers toward ecosystem. Furthermore, the numerical data has been considered for effectively and concisely describe the surveyed population. Qualitative research works on an in-depth understanding of the social world of foragers. Semi-structured interviews are the qualitative methods I utilized in this research. Yet, the statistical information pertaining to foragers as a population is generally lacking, due to the limited consideration they have traditionaly received. In order to provide a basic characterization, several quantitative survey questions were processed.

The data collection methods include semi-structured interviews, surveys, and autoethnography. The semi-structured interviews a qualitative research technique to 
address a wide variety of research interests. This exploratory approach focuses on the viewpoint of each forager. To do so, each forager is asked the same types of questions. Worth mention that, during the interviews, the fact of offering unintentional verbal or non-verbal cues has been particularly obeyed. A total of 10 interviews were conducted. Each interview lasted around thirty minutes. In the interview each forager shares his/her stories while presenting the reasons for foraging and the method they use. In addition, they share impacts foraging has had on their lives, and how this might impact others' lives.

\section{Implementation}

The participants for interviews were self-identified foragers, participated during the local markets and at the time of foraging at the sites. The qualitative research of 10 interviews was completed on-site. Interviewees were invited to participate in an interview with the consent to use the data for completing a UNESCO report. All interviewees except one asked for their quotes to remain anonymous and their names will not be revealed.

The interviewees whom I interviewed they were selected randomly at the sites during my field trips and the local market events. However, the locations that I have visited interviewees surely not have attracted all foragers. Thus, the foragers I worked with represents only a small group of individuals who were able to participate in the study. Through this investigation we aim at exploring who foragers in the Biospheres are and to describe the general characteristics of them. This characterization is especially relevant as there is a research gap in literature (Giesting, 2016).

Through 10 questions in two categories we aim at understanding foragers' environmental tendency and characteristics. However, we should note that this study does not cover the study on foragers' demographics in these two biospheres. Study on the demographics requires indeed higher funding for the study and statistics. Therefore, we have not estimation on the population of foragers. 


\section{Results}

The questionnaires for the interview have been adopted from Giesting (2016). Ten foragers have been identified and interviewed to reveal the characteristics of the business models that they are involved. To study the sustainability of the business model the details of their activities had been questioned to identify the profit making and the relation to ecosystem. For that the foragers' environmental tendency and characteristics had been carefully examined. The results of the interviews are summarized in the following bullet points:

- Most of foragers are from rural and small towns near the biospheres.

- They intent to do foraging for making profit to have a support for family expenses.

- Foraging is a passion, even though it is conducted for profit making.

- The value making process consists of foraging $\rightarrow$ drying $\rightarrow$ processing for tea making $\rightarrow$ packaging $\rightarrow$ sales.

- Foragers may have other occupations and through foraging they acquire extra value.

- Often foragers have unrelated professions (70\%) and a few of them retired (30\%).

- Foragers follow a deep environmental conviction and oppose the consumer behaviors.

- Majority of the foragers are satisfied with their life; they enjoy their life activity outdoor and they feel financially satisfied although they say it could be better. When they asked what will be doing if you inherit a huge amount of money they would choose to go traveling.

- Foragers are satisfied with their life generally and therefore they appear to rarely make unnecessary purchases.

- Foragers identify themselves as highly connected with local landscape and with environmentalism idea in general. In terms of environmental tendency, they considered themselves as protecting of the ecosystems. This has been the main reason of harvesting the plants in a sustainable manner.

- They preserve the ecosystems of the Biosphere Reserves and surrounding carefully through sustainable harvesting and foraging to be able to do so in the next season. They are also very conscious on the season of harvesting of every plant in order to 
support its survival for the next season. These practices are passed to the new generations.

- Foraging is a life style rather than a hobby.

- All foragers interviewed consider their local ecosystem to be extremely important.

- Major foragers interviewed had been a forage for more than 10 years or most of their life.

- All foragers interviewed consumed their own end products.

- Half of the foragers interviewed forage alone and half in a community or with friends

- In addition to make herbal tea, they forage because they do have prior interest in nature, the plants are healthy and make them closer to the nature.

- Foraging promotes environmental sustainability

- Foragers connect to the earth, and this promotes environmental concern and action amongst foragers.

- The profit from selling herbal teas are very limited, however it brings a feeling of satisfaction. And that is what really matters.

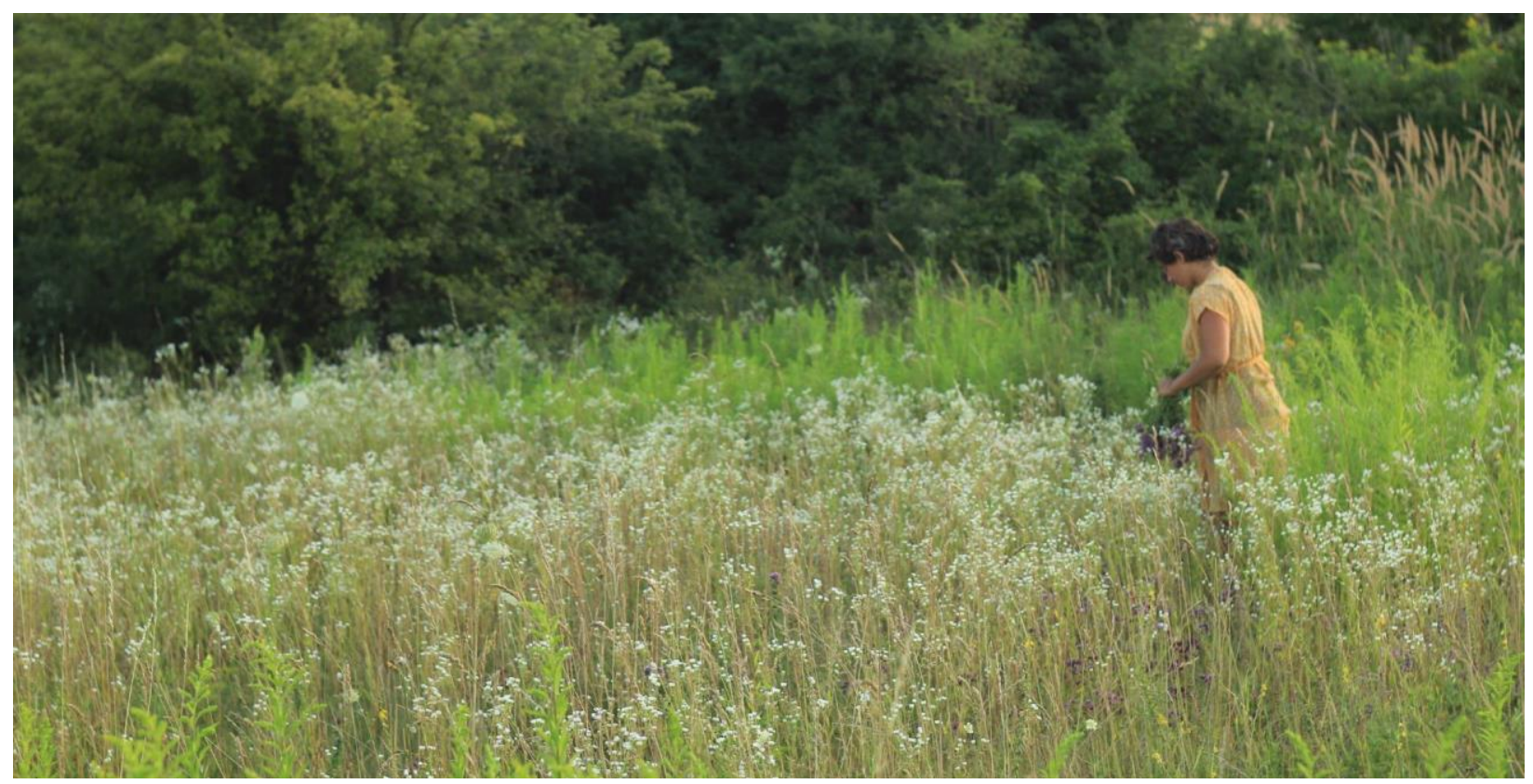

Figure 25. sustainable foraging practice (Photo credit: Dániel B. Kovács) 


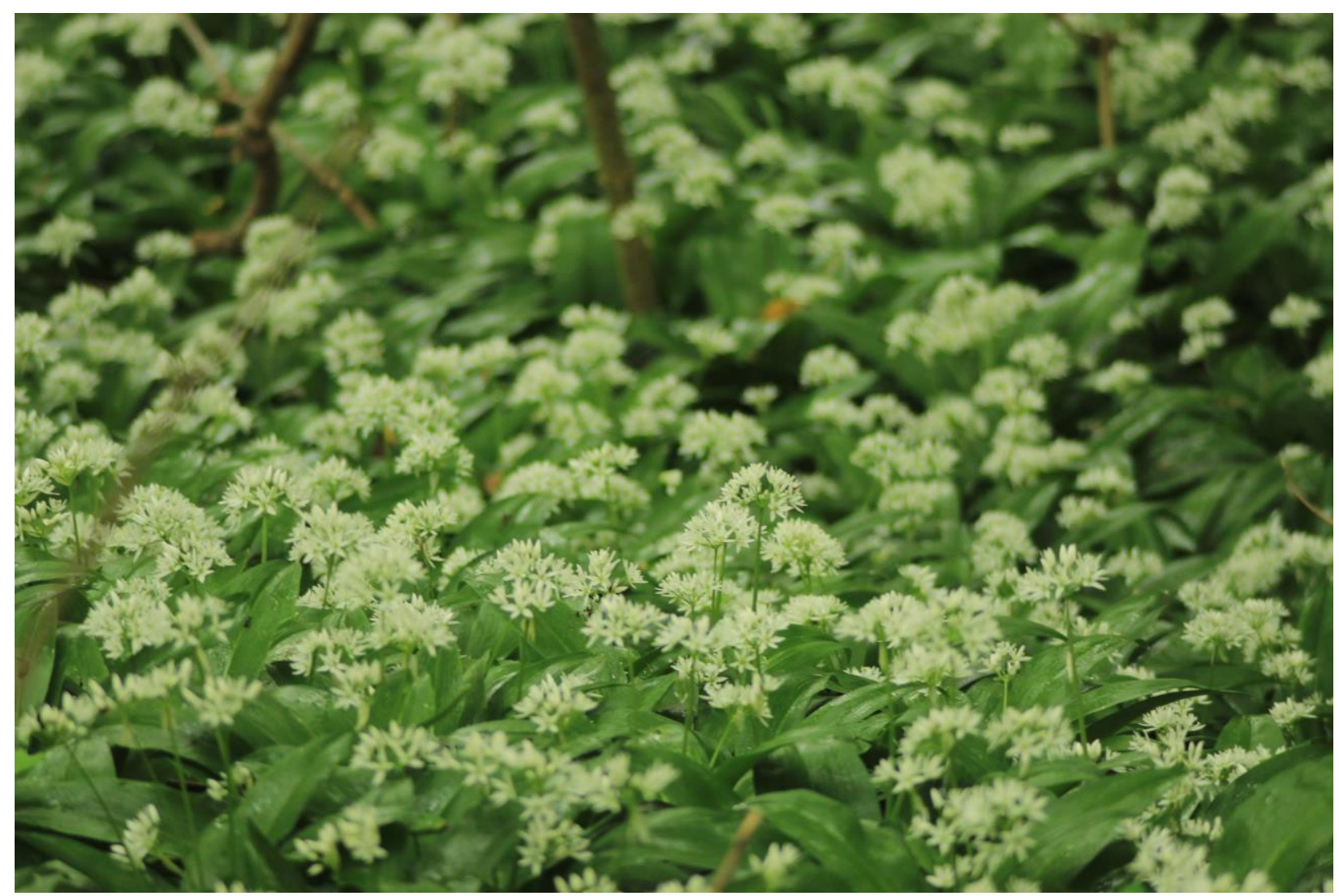

Figure 26. Medvehagyma / Beer leek (Photo credit: Dániel B. Kovács)



Figure 27. Mezei zsálya / Clary (Photo credit: Dániel B. Kovács)

Page | 42 


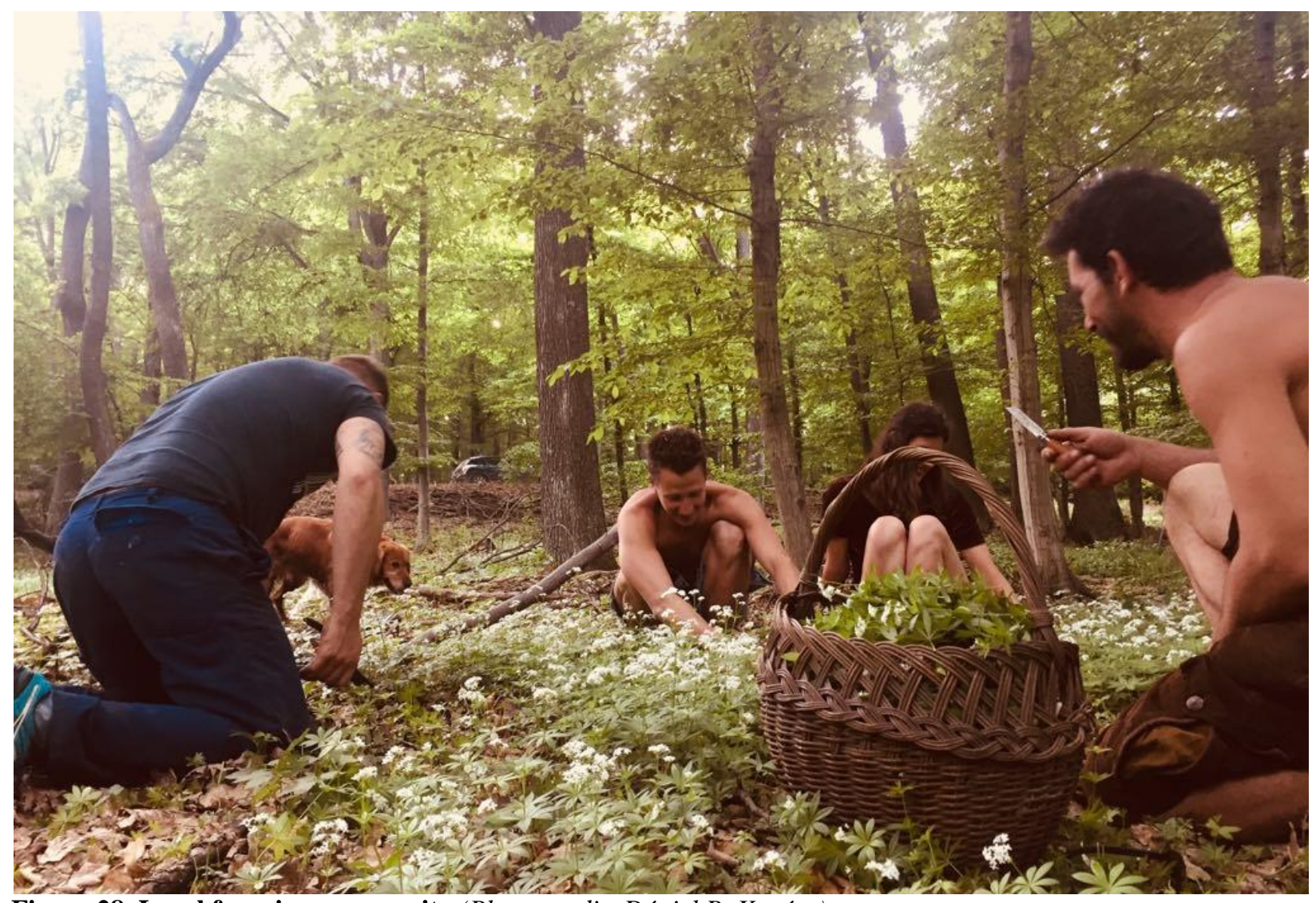

Figure 28. Local foraging community (Photo credit: Dániel B. Kovács) 


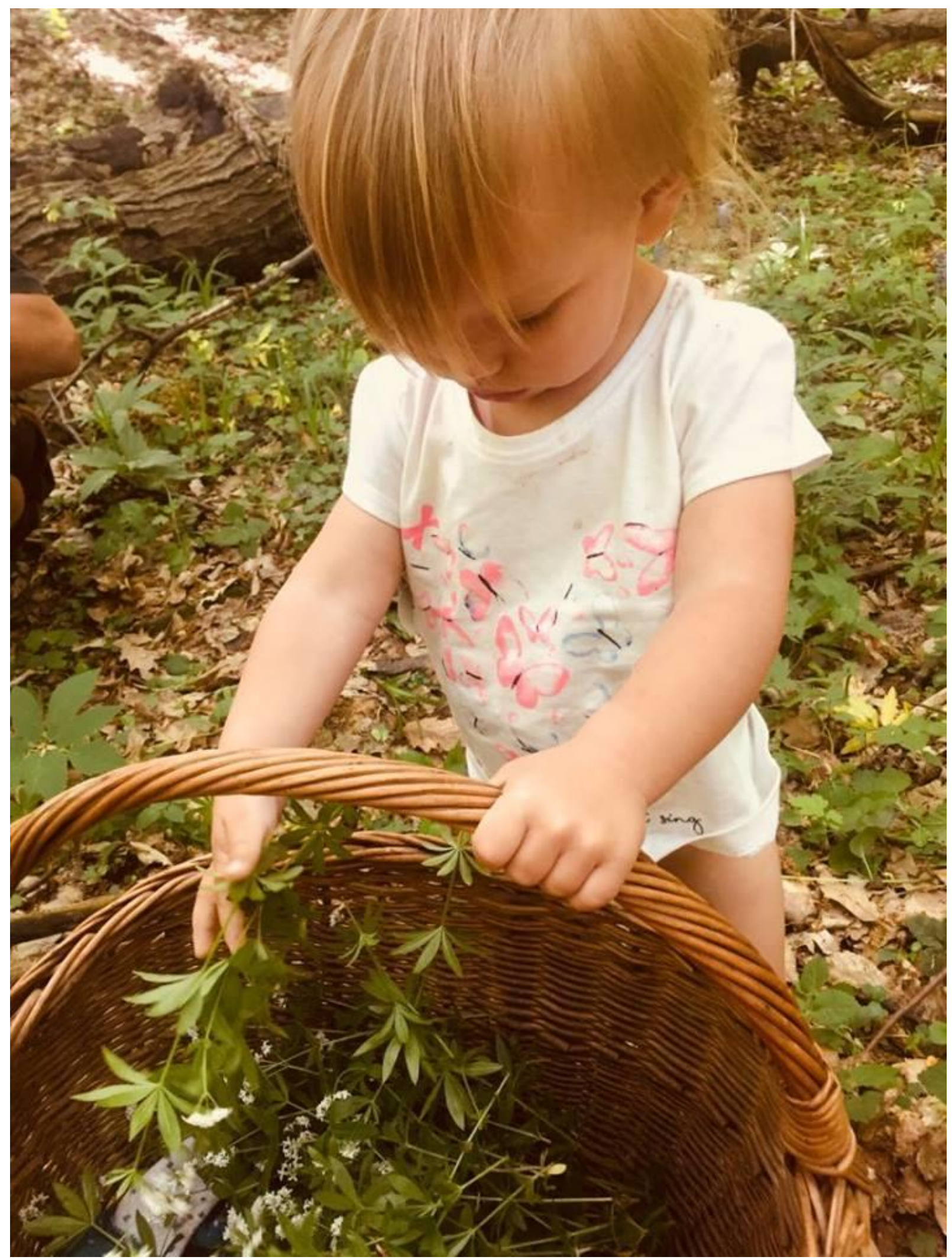

Figure 29. new generations are interested in sustainable foraging (Photo credit: Dániel B. Kovács) 


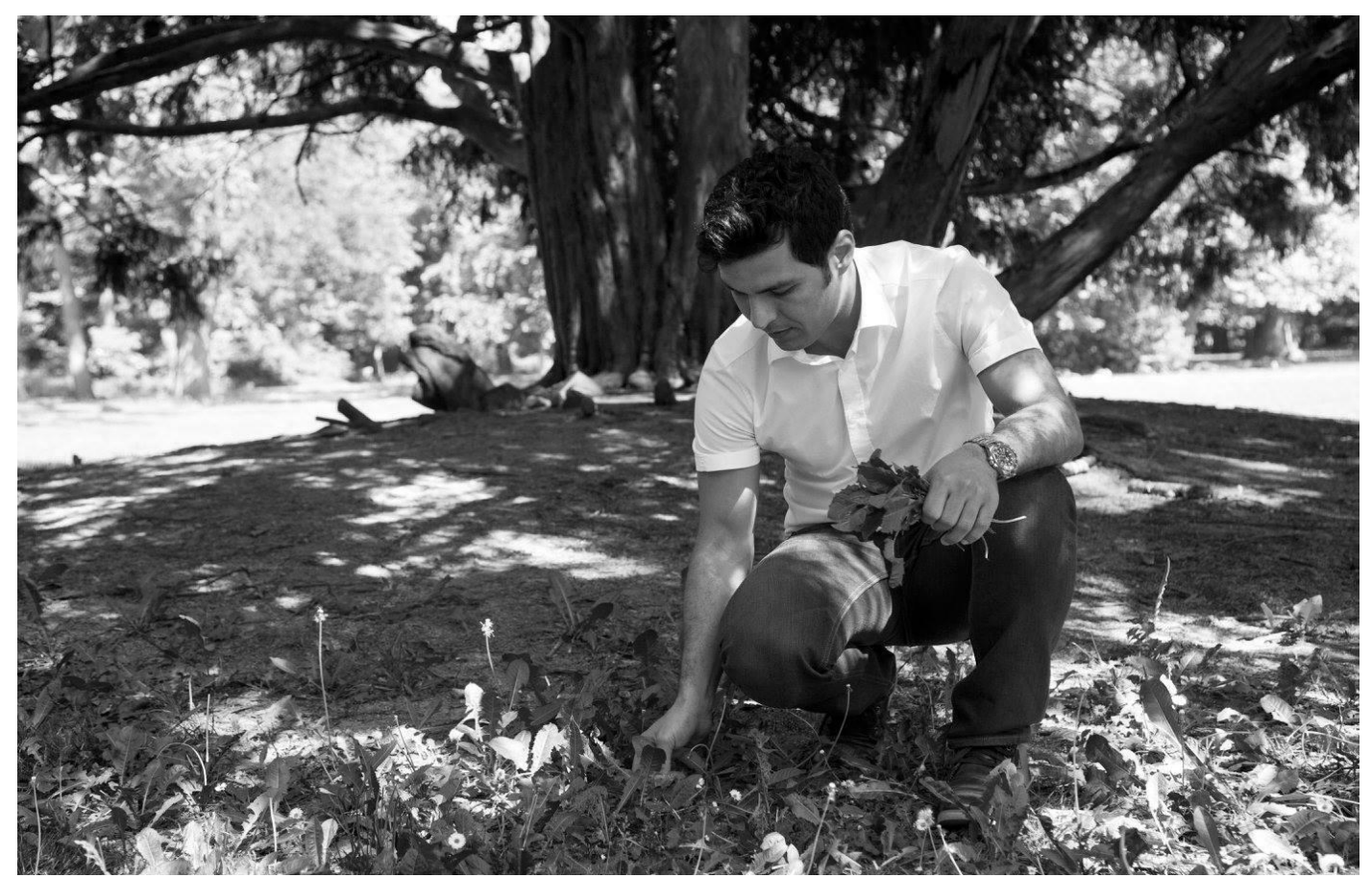

Figure 30. Fellow foraging around Kiskunság Biosphere Reserve (Photo credit: Amir Mosavi)

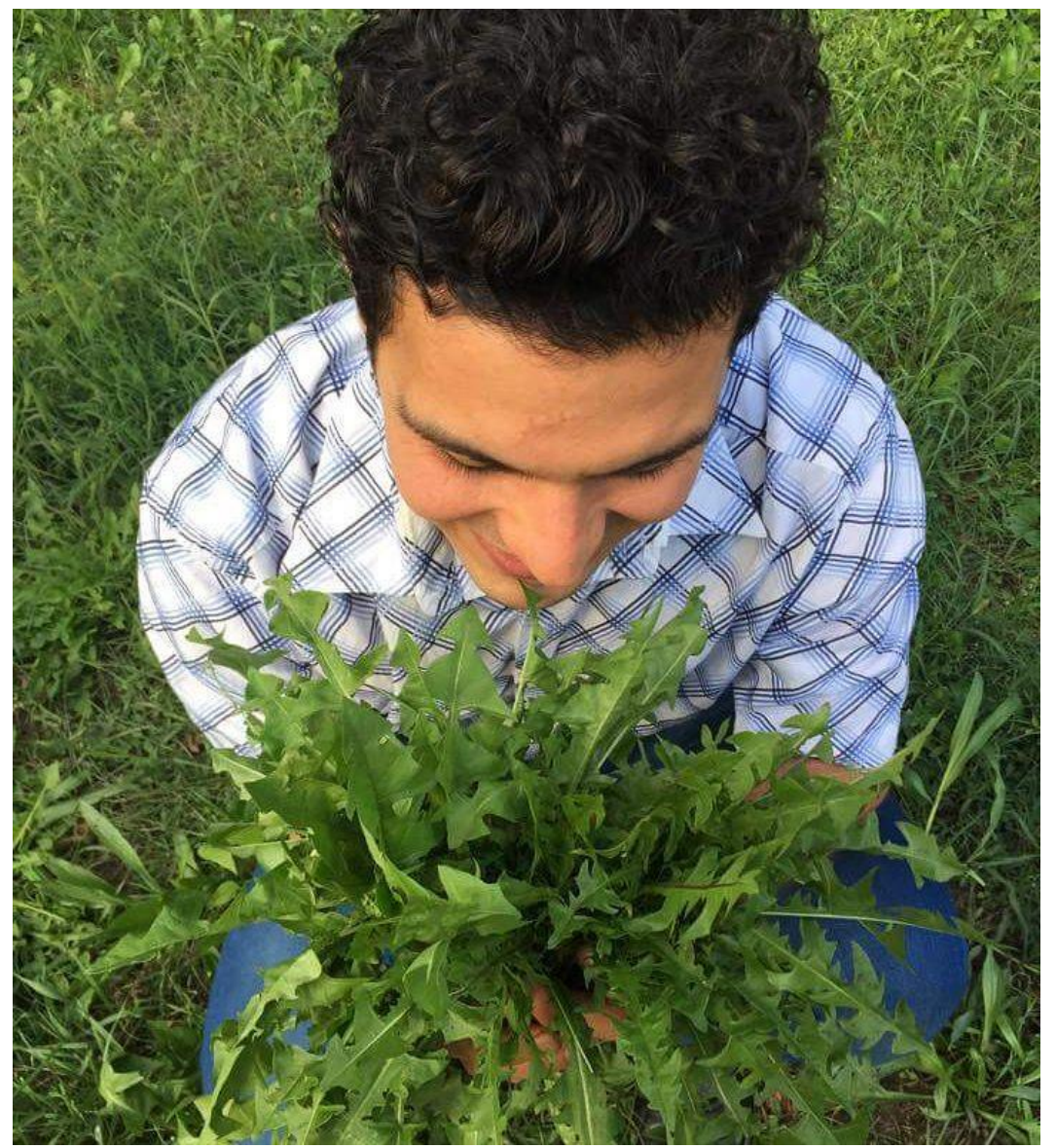

Figure 31. Fellow foraging around Kiskunság Biosphere Reserve (Photo credit: Amir Mosavi) 




Figure 32 drying (Photo credit: Amir Mosavi)

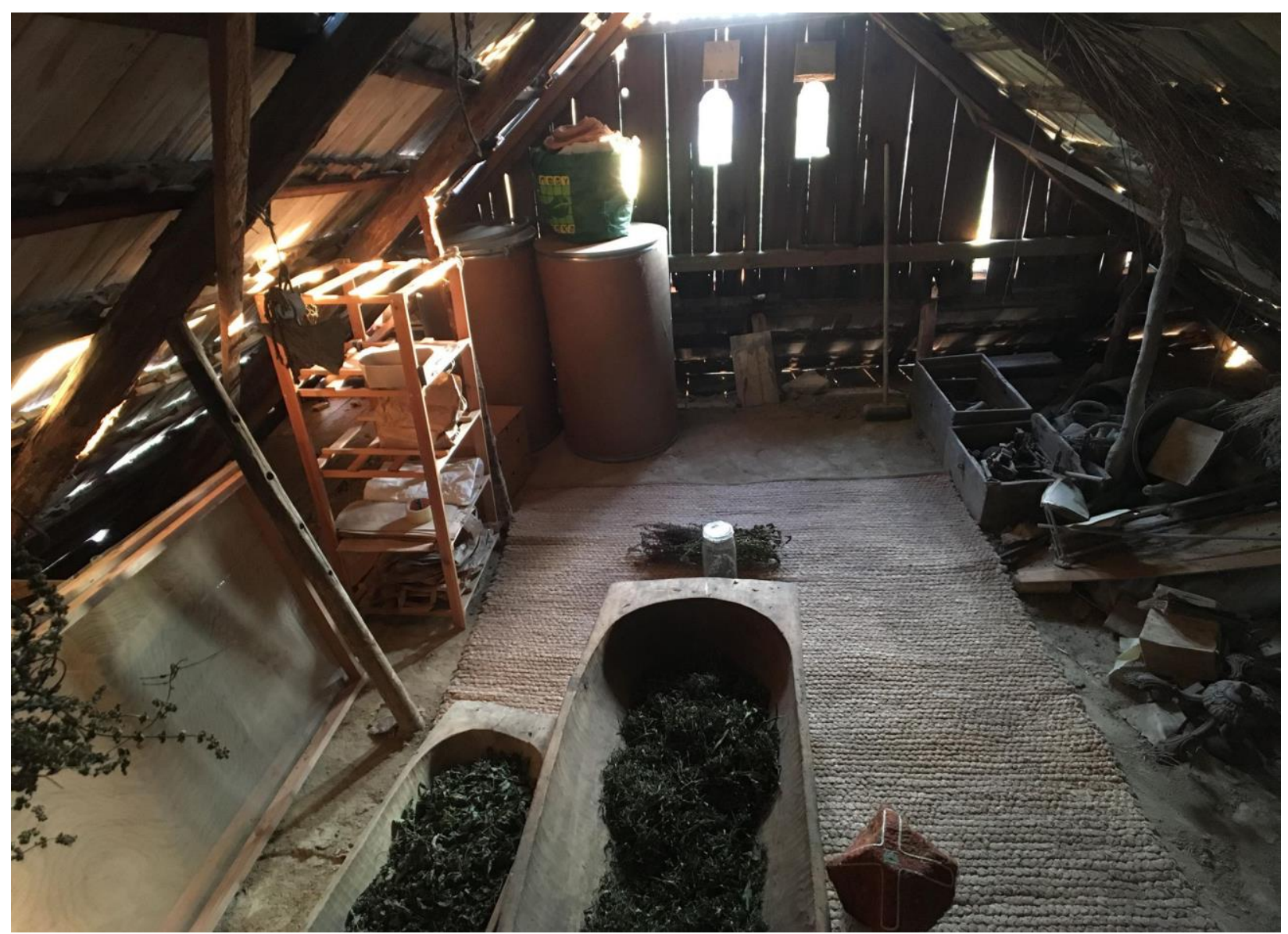

Figure 33. drying and processing plants (Photo credit: Dániel B. Kovács)

Page $\mid 46$ 


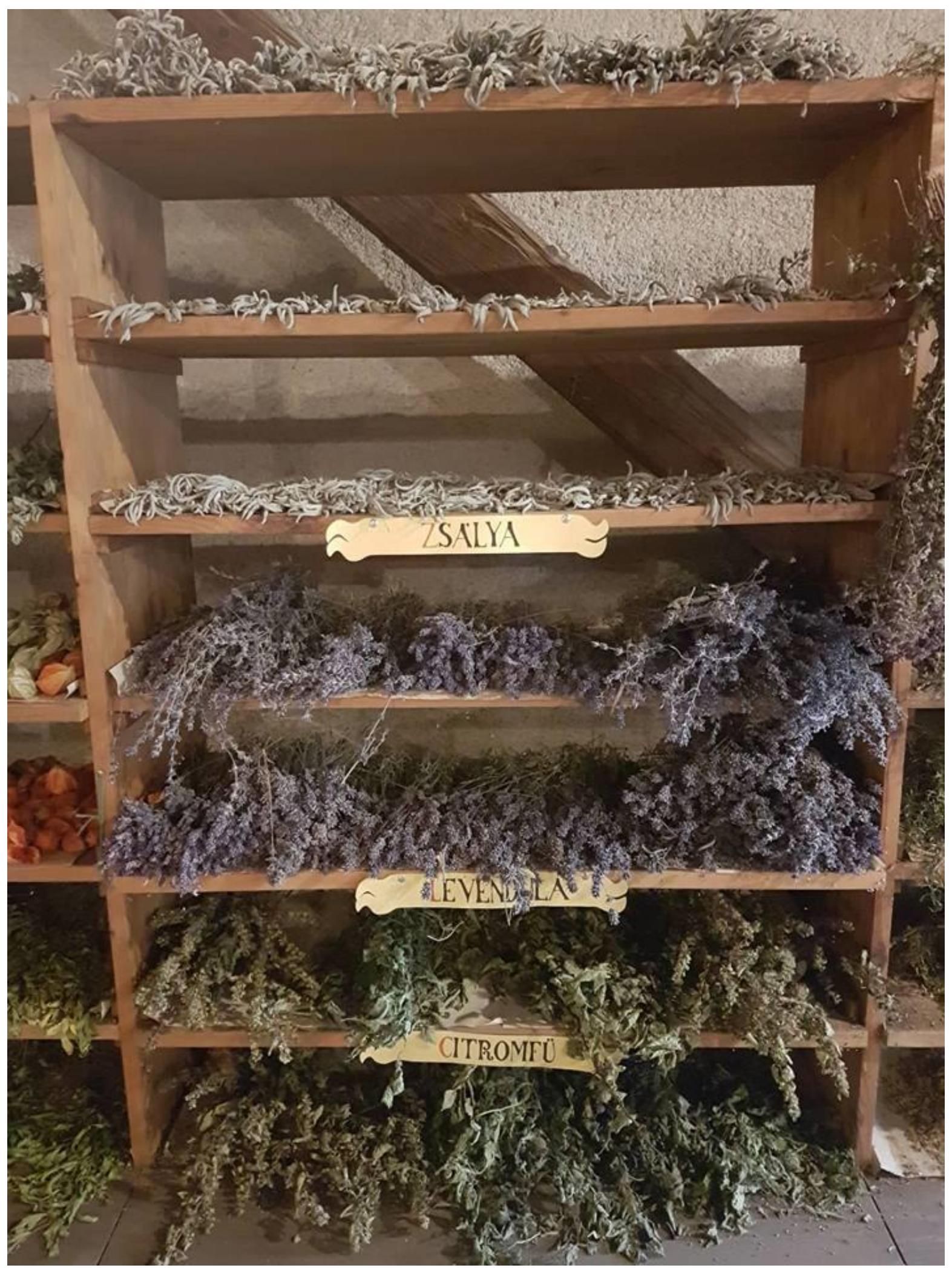

Figure 34. drying and processing plants (Photo credit: Amir Mosavi) 


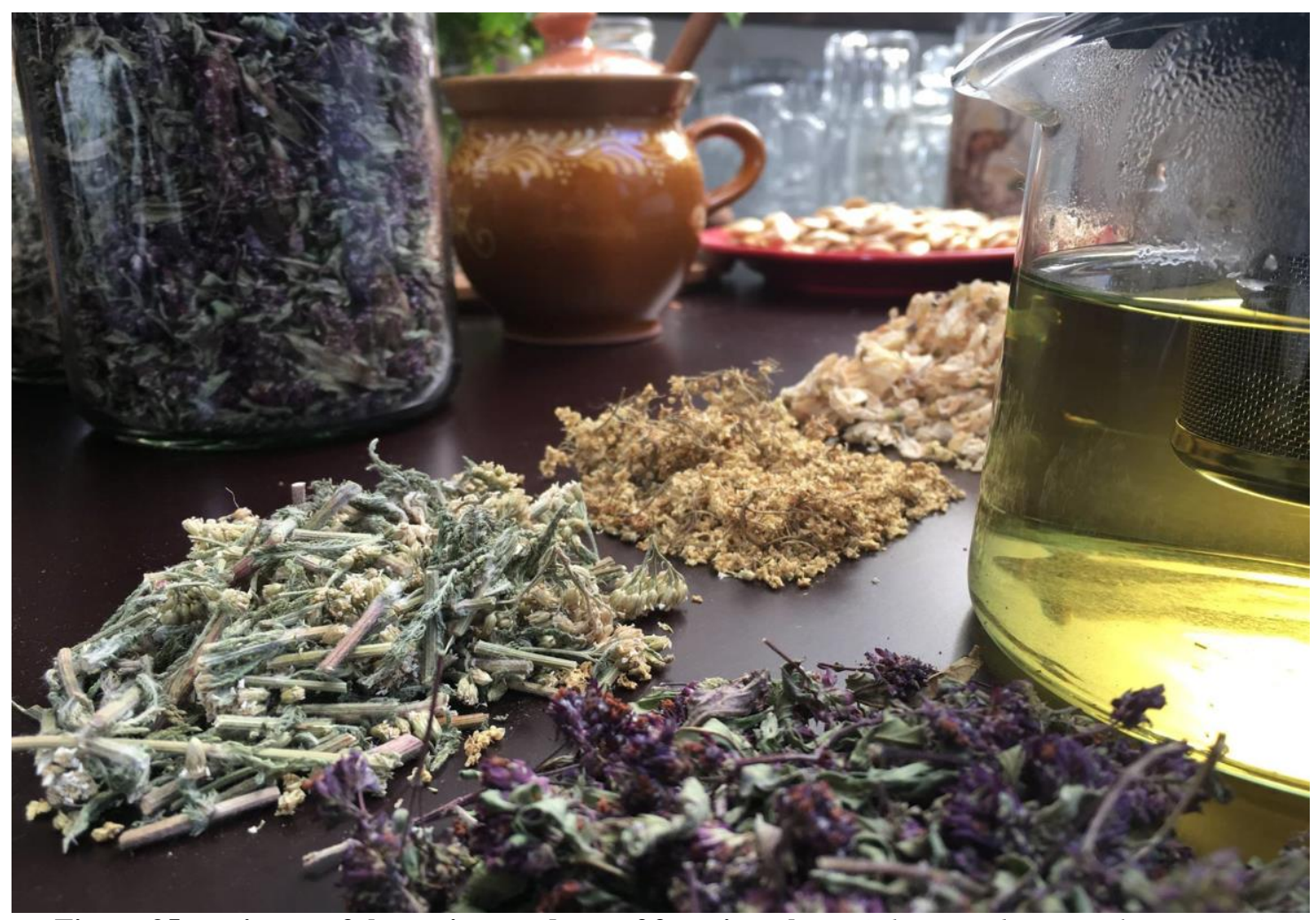

Figure 35. tea is one of the major products of foraging plants (Photo credit: Dániel B. Kovács)



Figure 36. community contribution on processing the plants (Photo credit: Dániel B. Kovács) 


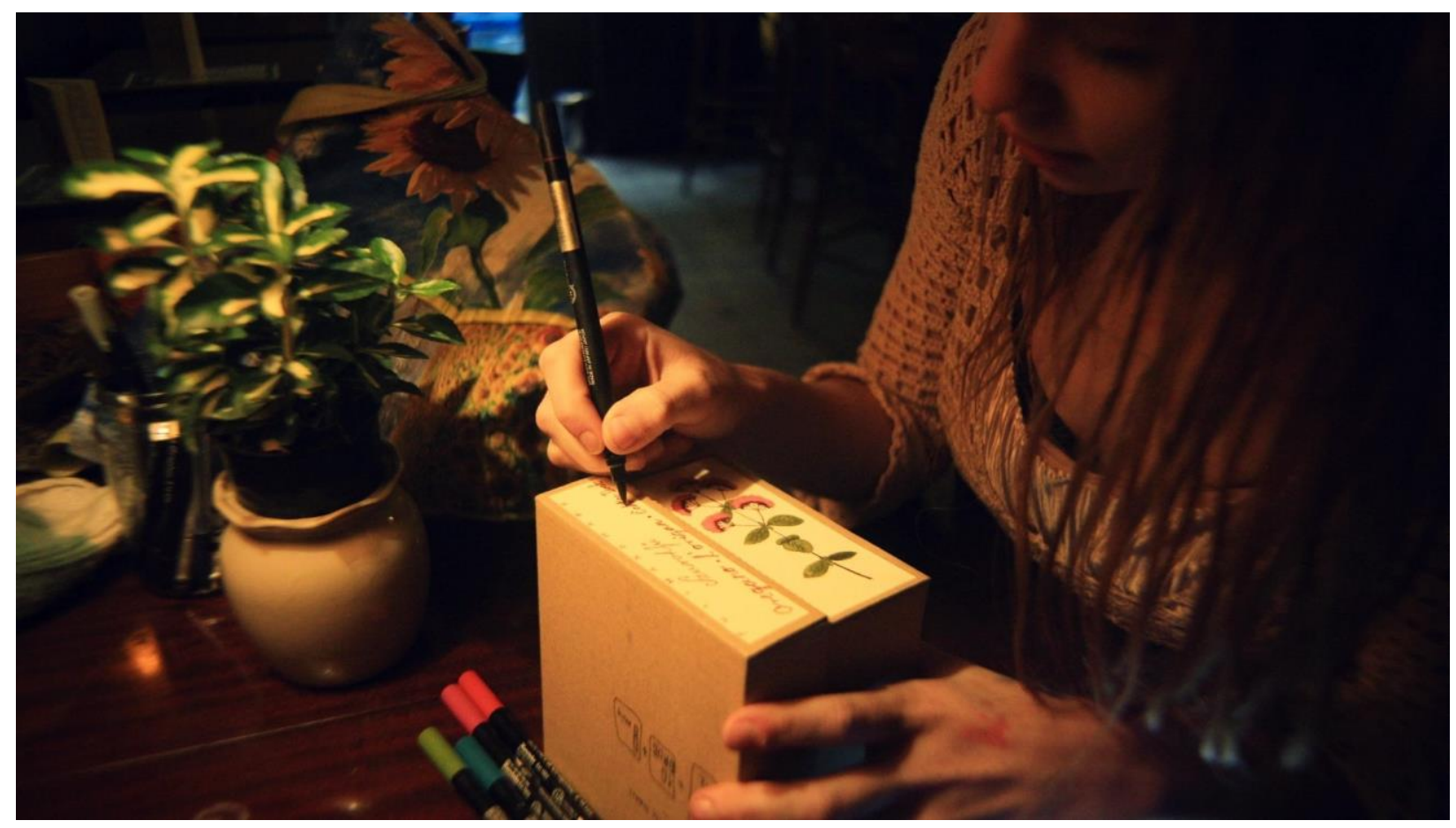

Figure 37. packaging for selling in a local market or personal use (Photo credit: Dániel B. Kovács)

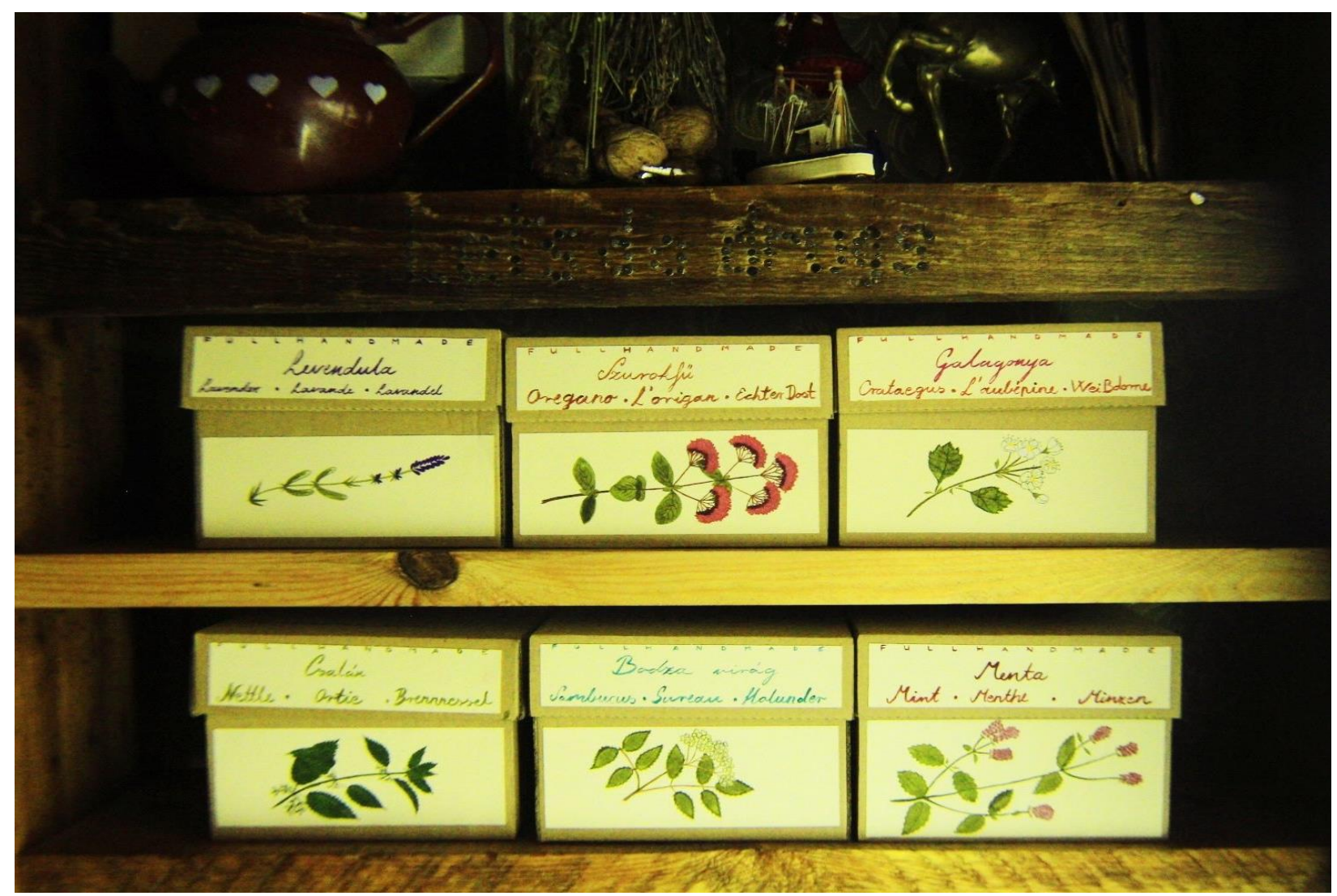

Figure 38. packaging for selling in a local market or personal use (Photo credit: Dániel B. Kovács)

Page $\mid 49$ 


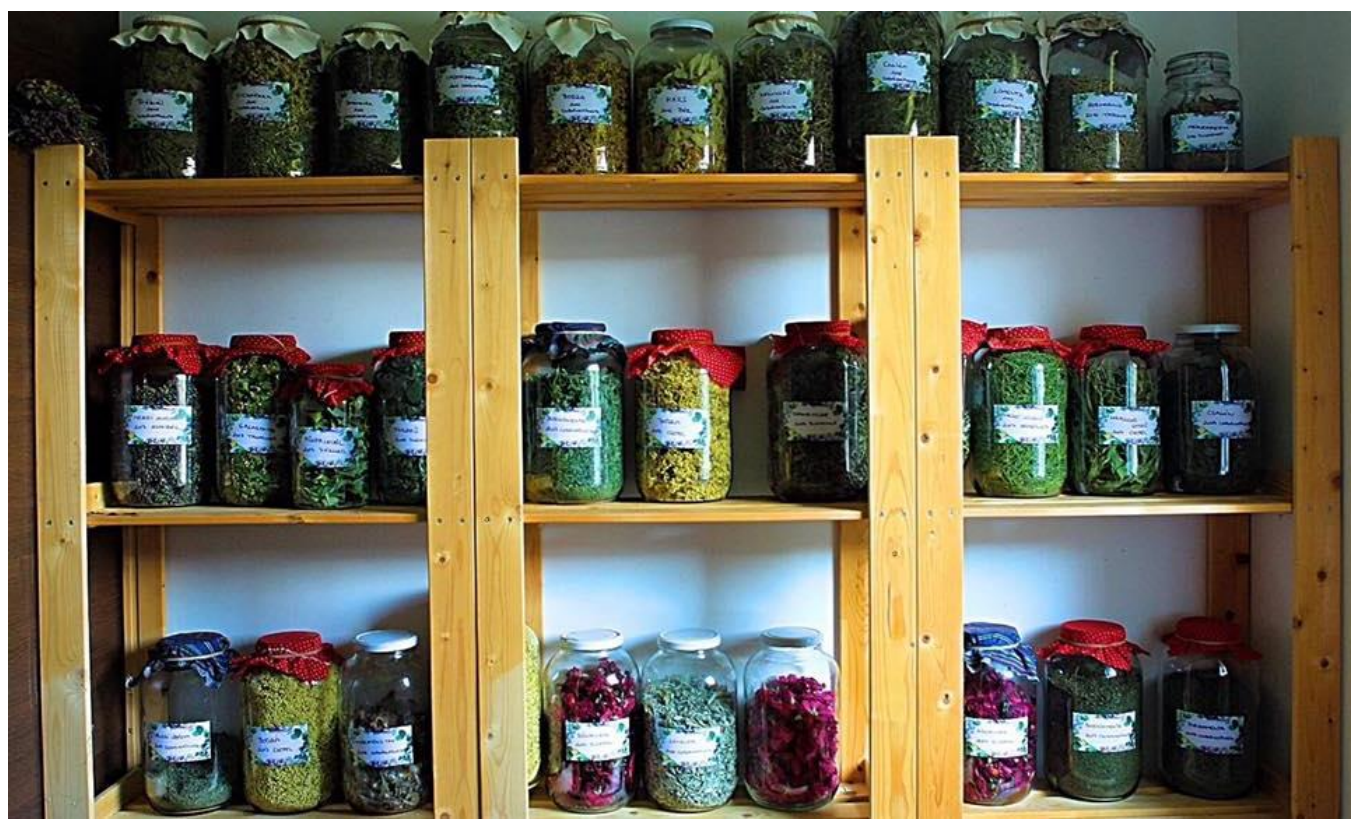

Figure 39. local tea house (Photo credit: Dániel B. Kovács)

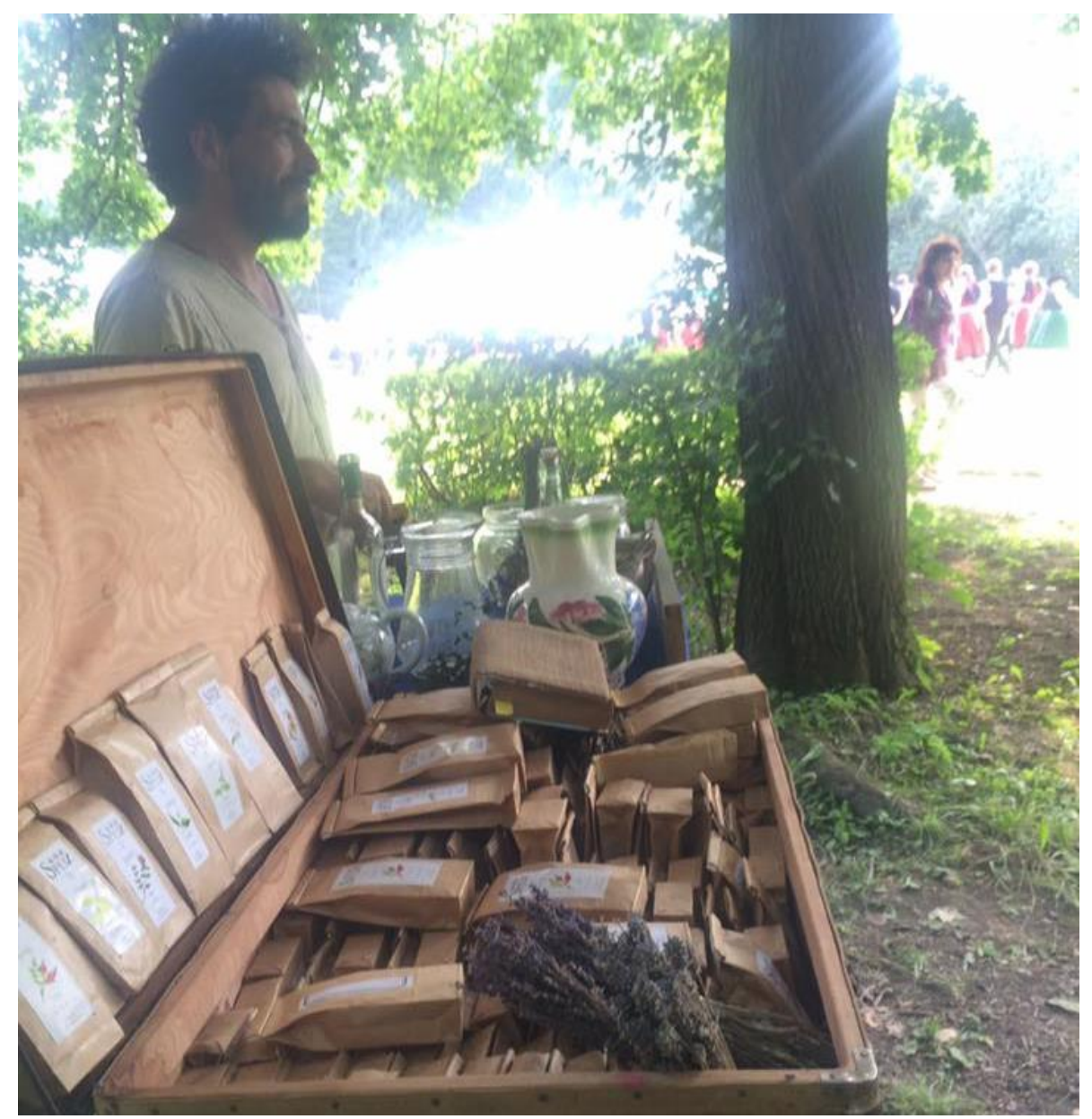

Figure 40. local sales of packaged plants as herbal teas (Photo credit: Dániel B. Kovács) 


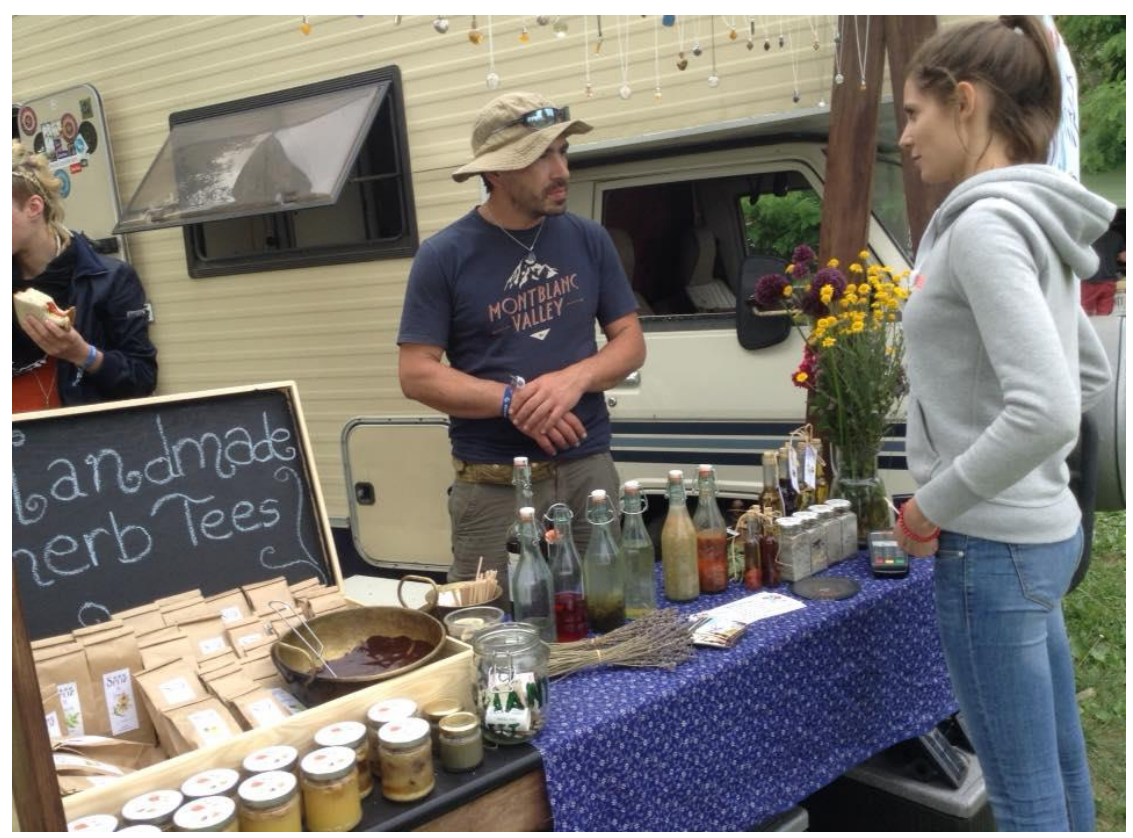

Figure 41. local sales of packaged plants as herbal teas (Photo credit: Dániel B. Kovács)

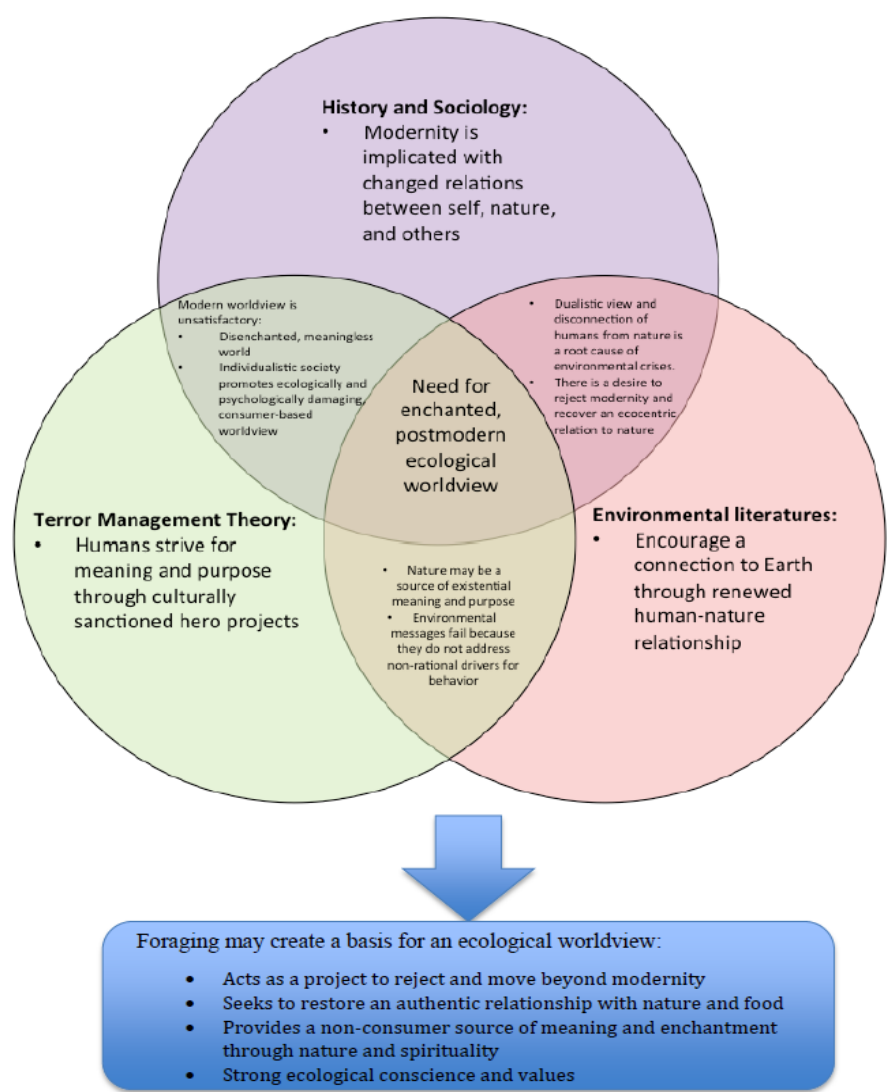

Figure 42 Conceptual Framework (Giesting - 2016) 


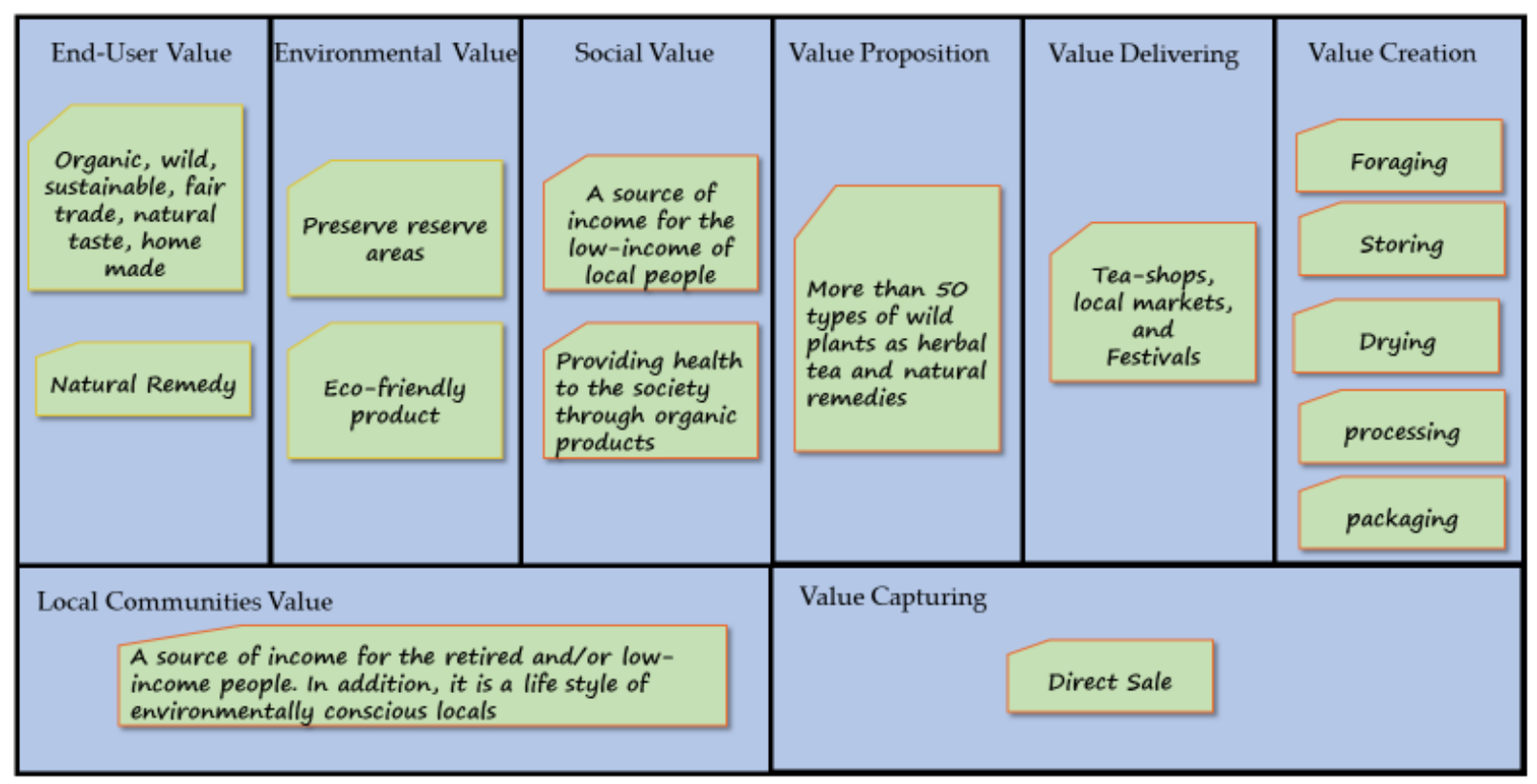

Figure 43. sustainable business model of foraging for Biosphere reserves

Figures 25-41 illustrates the process of "foraging for tea" sustainable business models. It includes foraging to packaging and sales. Pictures are taken in the surrounding areas and outer zones of biospheres reserves where foragers are much freer to do activities. As it is depicted in figure 47, the value proposition of the proposed business model constitutes more than 50 types of wild plants for tea and natural remedies production. To prepare the final product, the forager goes for foraging looking for the desired plants. The main value here is that these plants grow naturally without any human intervention and any chemical fertilizers. Collecting of the herbs take place very delicately that does not harm the plants. After collecting the herbs, they are processed and stored to be dried and then they are packed to be sold in local markets, tea houses and shops. The final products have been mainly sent to the tea-shops and these tea-shops are often the main channel to deliver the products to the final customers. In some cases, the forager is the owner of his/her small teashop business. Since, all the process normally conducted by one person, the costs of this business is minimized and limited to keeping the tea-shop store, in case the owner is the forager. The income model in this business model is direct sale and they charge the customers directly based on the purchase volume. 


\section{Conclusions}

This research present sustainable business models as an innovative tool for monitoring and assessment of sustainability in the biosphere reserves. The innovative tool contributes well in promoting the sustainability, efficient management of natural resources, and improving national and international communication as well as efficient monitoring and training. In this research the social, environmental and economical state of Kiskunság Biosphere Reserve, and Pilis Biosphere Reserve are monitored and well predicted for an acceptable assessment. The development of predictive business models offers such a possibility which create informed decisions and eliminate the trial-error costs. This would lead to sustainable business model where the relationships between people and their environments improved. When the business model is clearly documented it is easily understood and can clearly communicate the business model. This would promote a healthy balance of Man and Biosphere, via suggesting policies and strategies that can maintain a healthy relation between man and its environment.

Sustainable development is indeed the primary goal of all Biosphere reserves' management to relate with. Our research proposes an advanced monitoring system for sustainability assessment. The original research takes place at kiskunsag and Pilis Biosphere reserves in Hungary for perusing the initial case studies. However, the result research as an innovative solution, can be adapted by other Biosphere Reserves to promote sustainability. Consequently, the proposed research can well contribute to the sustainable development of other Biosphere Reserves. Therefore, better policies are made, and more sustainable actions are taken worldwide to ensure environmental sustainability and it further enhance people's livelihood.

This research proposed the model of foraging for tea as a sustainable business model which satisfies all the aspects for sustainability in biosphere researches while creating profit. Such model further enforces the relationship between the man and earth and maintain a great respect for ecosystem. Various variations of sustainable business models of foraging can be explored in different biosphere reserves according to the characteristics of the sites and their natural plants. 


\section{Acknowledgment}

I would like to thank Dániel B. Kovács for sharing his expertise on the sustainable foraging and edible plants, and $\mathrm{PhD}$ candidate Saeed Nosratabadi for supporting me with investigation on sustainable business models.

\section{References}

Abdelkafi, N. and K. Täuscher (2016). "Business models for sustainability from a system dynamics perspective." Organization \& Environment 29(1): 74-96.

Anwar, S. and R. Prasad (2018). "Framework for Future Telemedicine Planning and Infrastructure using 5G Technology." Wireless Personal Communications 100(1): 193-208.

Ashford, N. A. and R. P. Hall (2011). Technology, globalization, and sustainable development: Transforming the industrial state, Yale University Press.

Baldassarre, B., G. Calabretta, N. M. P. Bocken and T. Jaskiewicz (2017). "Bridging sustainable business model innovation and user-driven innovation: A process for sustainable value proposition design." Journal of Cleaner Production 147: 175-186.

Barth, H., P. O. Ulvenblad and P. Ulvenblad (2017). "Towards a conceptual framework of sustainable business model innovation in the agri-food sector: A systematic literature review." Sustainability (Switzerland) 9(9).

Biloslavo, R., C. Bagnoli and D. Edgar (2018). "An eco-critical perspective on business models: The value triangle as an approach to closing the sustainability gap." Journal of Cleaner Production 174: 746-762.

Bittencourt Marconatto, D. A., L. Barin-Cruz, M. Pozzebon and J. E. Poitras (2016). "Developing sustainable business models within BOP contexts: Mobilizing native capability to cope with government programs." Journal of Cleaner Production 129: $735-748$. 
Bocken, N. and S. Short (2016). "Towards a sufficiency-driven business model: Experiences and opportunities." Environmental Innovation and Societal Transitions 18: 41-61.

Bocken, N. M. P., S. W. Short, P. Rana and S. Evans (2014). "A literature and practice review to develop sustainable business model archetypes." Journal of Cleaner Production 65: 42-56.

Boo, E., E. Dallamaggiore, N. Dunphy and J. Morrissey (2016). "How innovative business models can boost the energy efficient buildings market." International Journal for Housing Science and Its Applications 40(2): 73-83.

Boons, F. and F. Lüdeke-Freund (2013). "Business models for sustainable innovation: state-of-the-art and steps towards a research agenda." Journal of Cleaner production 45: 9-19.

Boons, F., C. Montalvo, J. Quist and M. Wagner (2013). "Sustainable innovation, business models and economic performance: an overview." Journal of Cleaner Production 45: 1-8.

Brennan, G. and M. Tennant (2018). "Sustainable value and trade-offs: Exploring situational logics and power relations in a UK brewery's malt supply network business model." Business Strategy and the Environment 27(5): 621-630.

Buffa, F., M. Franch and D. Rizio (2018). "Environmental management practices for sustainable business models in small and medium sized hotel enterprises." Journal of Cleaner Production 194: 656-664.

Ciasullo, M. V., S. Cardinali and S. Cosimato (2018). "Exploring sustainable behaviour in international footwear supply chain management." International Journal of Business and Globalisation 20(3): 416-436.

Davies, I. A. and L. Chambers (2018). "Integrating hybridity and business model theory in sustainable entrepreneurship." Journal of Cleaner Production 177: 378-386. 
De Bernardi, P. and L. Tirabeni (2018). "Alternative food networks: sustainable business models for anti-consumption food cultures." British Food Journal 120(8): 1776-1791.

de Lange, D. E. (2017). "Start-up sustainability: An insurmountable cost or a lifegiving investment?" Journal of Cleaner Production 156: 838-854.

Dembek, K., J. York and P. J. Singh (2018). "Creating value for multiple stakeholders: Sustainable business models at the Base of the Pyramid." Journal of Cleaner Production 196: 1600-1612.

Dyllick, T. and K. Hockerts (2002). "Beyond the business case for corporate sustainability." Business strategy and the environment 11(2): 130-141.

Evans, S., D. Vladimirova, M. Holgado, K. Van Fossen, M. Yang, E. A. Silva and C. Y. Barlow (2017). "Business Model Innovation for Sustainability: Towards a Unified Perspective for Creation of Sustainable Business Models." Business Strategy and the Environment 26(5): 597-608.

Franceschelli, M. V., G. Santoro and E. Candelo (2018). "Business model innovation for sustainability: a food start-up case study." British Food Journal.

Gasbarro, F., F. Rizzi and M. Frey (2018). "Sustainable institutional entrepreneurship in practice: Insights from SMEs in the clean energy sector in Tuscany (Italy)." International Journal of Entrepreneurial Behaviour and Research 24(2): 476-498.

Geissdoerfer, M., N. M. Bocken and E. J. Hultink (2016). "Design thinking to enhance the sustainable business modelling process-A workshop based on a value mapping process." Journal of Cleaner Production 135: 1218-1232.

Geissdoerfer, M., S. N. Morioka, M. M. de Carvalho and S. Evans (2018). "Business models and supply chains for the circular economy." Journal of Cleaner Production 190: 712-721. 
Geissdoerfer, M. B., N. M. P.; Hultink, E. J. (2016). "Design thinking to enhance the sustainable business modelling process - A workshop based on a value mapping process." Journal of Cleaner Production 135: 1218-1232.

Goyal, S., B. S. Sergi and A. Kapoor (2017). "Emerging role of for-profit social enterprises at the base of the pyramid: the case of Selco." Journal of Management Development 36(1): 97-108.

Heyes, G., M. Sharmina, J. M. F. Mendoza, A. Gallego-Schmid and A. Azapagic (2018). "Developing and implementing circular economy business models in serviceoriented technology companies." Journal of Cleaner Production 177: 621-632.

Hirscher, A. L., K. Niinimäki and C. M. Joyner Armstrong (2018). "Social manufacturing in the fashion sector: New value creation through alternative design strategies?" Journal of Cleaner Production 172: 4544-4554.

Høgevold, N. M., G. Svensson, C. Padin and M. Dos Santos (2016). "A comparison of sustainable business models between goods and service industries: Similarities and differences." International Journal of Business Excellence 10(1): 20-36.

Høgevold, N. M. and G. P. Svensson, C. (2015). "A sustainable business model in services: An assessment and validation." International Journal of Quality and Service Sciences 7(1): 17-33.

Joyce, A. and R. L. Paquin (2016). "The triple layered business model canvas: A tool to design more sustainable business models." Journal of Cleaner Production 135: 1474-1486.

Jung, S. and B. Jin (2016). "Sustainable development of slow fashion businesses: Customer value approach." Sustainability (Switzerland) 8(6).

Khalid, K., S. F. Hassam and A. M. Ahmad (2016). "Inducing the entrepreneurial action theory into sustainable-business model: An alternative to entrepreneurship theory." Advanced Science Letters 22(5-6): 1188-1191. 
Kozlowski, A., C. Searcy and M. Bardecki (2018). "The reDesign canvas: Fashion design as a tool for sustainability." Journal of Cleaner Production 183: 194-207.

Kurucz, E. C., B. A. Colbert, F. Lüdeke-Freund, A. Upward and B. Willard (2017). "Relational leadership for strategic sustainability: practices and capabilities to advance the design and assessment of sustainable business models." Journal of Cleaner Production 140: 189-204.

Lee, S. S. and S. Slocum (2015). "Understanding the Role of Local Food in the Meeting Industry: An Exploratory Study of Meeting Planners' Perception of Local Food in Sustainable Meeting Planning." Journal of Convention and Event Tourism 16(1): 45-60.

Melissen, F., E. Cavagnaro, M. Damen and A. Düweke (2016). "Is the hotel industry prepared to face the challenge of sustainable development?" Journal of Vacation Marketing 22(3): 227-238.

Merchant, K. A., M. M. Ward and K. J. Mueller (2015). "Hospital Views of Factors Affecting Telemedicine Use." Rural policy brief(2015 5): 1-4.

Morioka, S. N., I. Bolis, S. Evans and M. M. Carvalho (2018). "Transforming sustainability challenges into competitive advantage: Multiple case studies kaleidoscope converging into sustainable business models." Journal of Cleaner Production 167: 723-738.

Moschetti, R., H. Brattebø, K. S. Skeie and A. G. Lien (2018). "Performing quantitative analyses towards sustainable business models in building energy renovation projects: Analytic process and case study." Journal of Cleaner Production 199: 1092-1106.

Neumeyer, X. and S. C. Santos (2018). "Sustainable business models, venture typologies, and entrepreneurial ecosystems: A social network perspective." Journal of Cleaner Production 172: 4565-4579. 
Nichifor, M. A. (2015). "Sustainable business models for wind and solar energy in Romania." Management and Marketing 10(1): 52-60.

Nikou, S. and H. Bouwman (2017). "Mobile health and wellness applications: A business model ontology-based review." International Journal of e-Business Research 13(1): 1-24.

Oskam, I., B. Bossink and A. P. de Man (2018). "The interaction between network ties and business modeling: Case studies of sustainability-oriented innovations." Journal of Cleaner Production 177: 555-566.

Pal, R. and J. Gander (2018). "Modelling environmental value: An examination of sustainable business models within the fashion industry." Journal of Cleaner Production 184: 251-263.

Palomares-Aguirre, I., M. Barnett, F. Layrisse and B. W. Husted (2018). "Built to scale? How sustainable business models can better serve the base of the pyramid." Journal of Cleaner Production 172: 4506-4513.

Porter, M. E. and M. R. Kramer (2011). "The big idea: Creating shared value." Harvard Business Review 89: 62-77.

Rashid, A., F. M. Asif, P. Krajnik and C. M. Nicolescu (2013). "Resource Conservative Manufacturing: an essential change in business and technology paradigm for sustainable manufacturing." Journal of Cleaner production 57: 166177.

Rauter, R., J. Jonker and R. J. Baumgartner (2017). "Going one's own way: drivers in developing business models for sustainability." Journal of Cleaner Production 140: 144-154.

Ray, A. and S. Mondal (2017). "Study of collaborative PRM business model for sustainability." Benchmarking 24(7): 1891-1911. 
Robinson, C., S. Cloutier and H. Eakin (2017). "Examining the business case and models for sustainable multifunctional edible landscaping enterprises in the Phoenix metro area." Sustainability (Switzerland) 9(12).

Roman, M., J. Liu and T. Nyberg (2018). "Advancing the open science movement through sustainable business model development." Industry and Higher Education 32(4): 226-234.

Rossignoli, F. and A. Lionzo (2018). "Network impact on business models for sustainability: Case study in the energy sector." Journal of Cleaner Production 182: 694-704.

Selberherr, J. (2015). "Sustainable life cycle offers through cooperation." Smart and Sustainable Built Environment 4(1): 4-24.

Sousa-Zomer, T. T. and P. A. Cauchick Miguel (2018). "Sustainable business models as an innovation strategy in the water sector: An empirical investigation of a sustainable product-service system." Journal of Cleaner Production 171: S119-S129.

Stål, H. I. and H. Corvellec (2018). "A decoupling perspective on circular business model implementation: Illustrations from Swedish apparel." Journal of Cleaner Production 171: 630-643.

Stubbs, W. (2017). "Characterising B Corps as a sustainable business model: An exploratory study of B Corps in Australia." Journal of Cleaner Production 144: 299312.

Stubbs, W. and C. Cocklin (2008). "Conceptualizing a "sustainability business model"." Organization \& Environment 21(2): 103-127.

Todeschini, B. V., M. N. Cortimiglia, D. Callegaro-de-Menezes and A. Ghezzi (2017). "Innovative and sustainable business models in the fashion industry: Entrepreneurial drivers, opportunities, and challenges." Business Horizons 60(6): 759-770. 
Tolkamp, J., J. C. C. M. Huijben, R. M. Mourik, G. P. J. Verbong and R. Bouwknegt (2018). "User-centred sustainable business model design: The case of energy efficiency services in the Netherlands." Journal of Cleaner Production 182: 755-764.

Vachani, S. and N. C. Smith (2008). "Socially responsible distribution: distribution strategies for reaching the bottom of the pyramid." California Management Review 50(2): 52-84.

Wasiluk, K. L. (2013). "Beyond eco-efficiency: Understanding CS through the IC practice lens." Journal of Intellectual Capital 14(1): 102-126.

Witjes, S. and R. Lozano (2016). "Towards a more Circular Economy: Proposing a framework linking sustainable public procurement and sustainable business models." Resources, Conservation and Recycling 112: 37-44.

Zhang, W., J. Guo, F. Gu and X. Gu (2018). "Coupling life cycle assessment and life cycle costing as an evaluation tool for developing product service system of high energy-consuming equipment." Journal of Cleaner Production 183: 1043-1053.

Giesting, K., 2016. Foraging for Meaning: Harvesting Wild Plants as the Basis for an Ecological Worldview (Master's thesis, University of Waterloo).

Jurjonas, Matthew, Katie Crossman, Jennifer Solomon, and Walter Lopez Baez. "Potential links between certified organic coffee and deforestation in a protected area in Chiapas, Mexico." World Development 78 (2016): 13-21.

Puyravaud, J.P. and Davidar, P., 2013. The Nilgiris Biosphere Reserve: an unrealized vision for conservation. Tropical Conservation Science, 6(4), pp.468-476.

Zebich-Knos, M., 2008. Ecotourism, park systems, and environmental justice in Latin America. Environmental justice in Latin America: problems, promise, and practice, pp.185-211.

Raufflet, E., Berranger, A. and Gouin, J.F., 2008. Innovation in business-community partnerships: evaluating the impact of local enterprise and global investment models 
on poverty, bio-diversity and development. Corporate Governance: The international journal of business in society, 8(4), pp.546-556.

Ernsteins, R., Lubuze, M., Lontone, A., Zvirbule, L., Antons, V., Zilniece, I., Kaulins, J. and Vasarina, L., 2012. Climate change adaptation integration into Coastal Municipal Development: governance environment and communication preconditions. International Multidisciplinary Scientific GeoConference: SGEM: Surveying Geology \& mining Ecology Management, 5, p.1077.

Griscom, B.W. and Goodman, R.C., 2015. Reframing the sharing vs sparing debate for tropical forestry landscapes. Journal of Tropical Forest Science, 27(2), pp.145147.

Wei, F., 2014. Compendium of Best Practices in Sustainable Tourism. Prepared for United Nations Department of Economic and Social Affairs [online] https://sustainabledevelopment. un. org/content/documents/3322Compendium\% 20of\% 20Best, 20.

Crozat, D., 2013, Tourism development in UNESCO biosphere reserves: a typology of action. In ASSURE International Conference.

Gross, M., 2015. Twenty-five years of climate change failure.

Fulton ST, Caamal JA, Ribot CO, Lucas BE, Garcia CI, Bourillon LU, Flores EG. Coral reef monitoring with fishers' participation in Quintana Roo, Mexico: building social capital to preserve marine ecosystems. InProceedings of the Gulf and Caribbean Fisheries Institute 2013 (pp. 4-8).

Knaus, F., 2013. Lessons learnt from a monitoring endeavour in the UNESCO Biosphere Reserve Entlebuch. eco. mont-Journal on Protected Mountain Areas Research, 5, pp.55-58.

LeQuire, S.L. and Van Gilder, K., 2009. Caring for Creation and Culture: A Survey of Evangelical Involvement in Ecotourism with a Proposed Theological Framework. Transformation, 26(2), pp.118-129. 
Liu, C.H., Hong, C.Y. and Li, J.F., 2013. The determinants of ecotourism behavioral intentions.

Hong, S.K., 2015. Socio-economic foundation by biocultural resources management: Suggestion for UNESCO Shinan Dadohae Biosphere Reserve, Korea. Journal of Marine and Island Cultures, 4(2), pp.81-88.

A. Mosavi \& A. Delavar, Business Modeling, Obuda University, Budapest, 2016

Campbell, C., 2017. Biosphere Reserves: An'Enabling Space'for Communities.

Nosratabadi, S.; Mosavi, A.; Shamshirband, S.; Kazimieras Zavadskas, E.; Rakotonirainy, A.; Chau, K.W. Sustainable Business Models: A Review. Sustainability 2019, 11, 1663.

Ijadi Maghsoodi, A.; Ijadi Maghsoodi, A.; Mosavi, A.; Rabczuk, T.; Zavadskas, E.K. Renewable Energy Technology Selection Problem Using Integrated H-SWARAMULTIMOORA Approach. Sustainability 2018, 10, 4481. 